\title{
Heating system energy flexibility of low-energy residential buildings
}

\author{
Foteinaki, Kyriaki; Li, Rongling; Heller, Alfred; Rode, Carsten
}

Published in:

Energy and Buildings

Link to article, DOI:

10.1016/j.enbuild.2018.09.030

Publication date:

2018

Document Version

Peer reviewed version

Link back to DTU Orbit

Citation (APA):

Foteinaki, K., Li, R., Heller, A., \& Rode, C. (2018). Heating system energy flexibility of low-energy residential buildings. Energy and Buildings, 180, 95-108. https://doi.org/10.1016/j.enbuild.2018.09.030

\section{General rights}

Copyright and moral rights for the publications made accessible in the public portal are retained by the authors and/or other copyright owners and it is a condition of accessing publications that users recognise and abide by the legal requirements associated with these rights.

- Users may download and print one copy of any publication from the public portal for the purpose of private study or research.

- You may not further distribute the material or use it for any profit-making activity or commercial gain

- You may freely distribute the URL identifying the publication in the public portal 


\section{Accepted Manuscript}

Heating system energy flexibility of low-energy residential buildings

Kyriaki Foteinaki, Rongling Li , Alfred Heller, Carsten Rode

PII:

S0378-7788(18)31455-5

DOI:

https://doi.org/10.1016/j.enbuild.2018.09.030

Reference:

ENB 8816

To appear in:

Energy \& Buildings

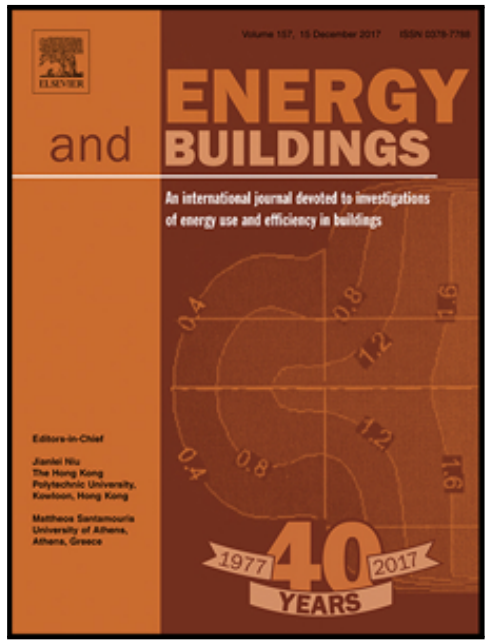

Received date: $\quad 12$ May 2018

Revised date: $\quad 20$ September 2018

Accepted date: $\quad 21$ September 2018

Please cite this article as: Kyriaki Foteinaki, Rongling Li, Alfred Heller, Carsten Rode, Heating system energy flexibility of low-energy residential buildings, Energy \& Buildings (2018), doi: https://doi.org/10.1016/j.enbuild.2018.09.030

This is a PDF file of an unedited manuscript that has been accepted for publication. As a service to our customers we are providing this early version of the manuscript. The manuscript will undergo copyediting, typesetting, and review of the resulting proof before it is published in its final form. Please note that during the production process errors may be discovered which could affect the content, and all legal disclaimers that apply to the journal pertain. 


\section{Highlights}

- Low-energy buildings are highly robust and remain autonomous for several hours.

- Heat losses govern flexibility potential while thermal mass has secondary impact.

- The potential for storage in the thermal mass is higher than for curtailment.

- High dependence of flexibility potential on boundary conditions.

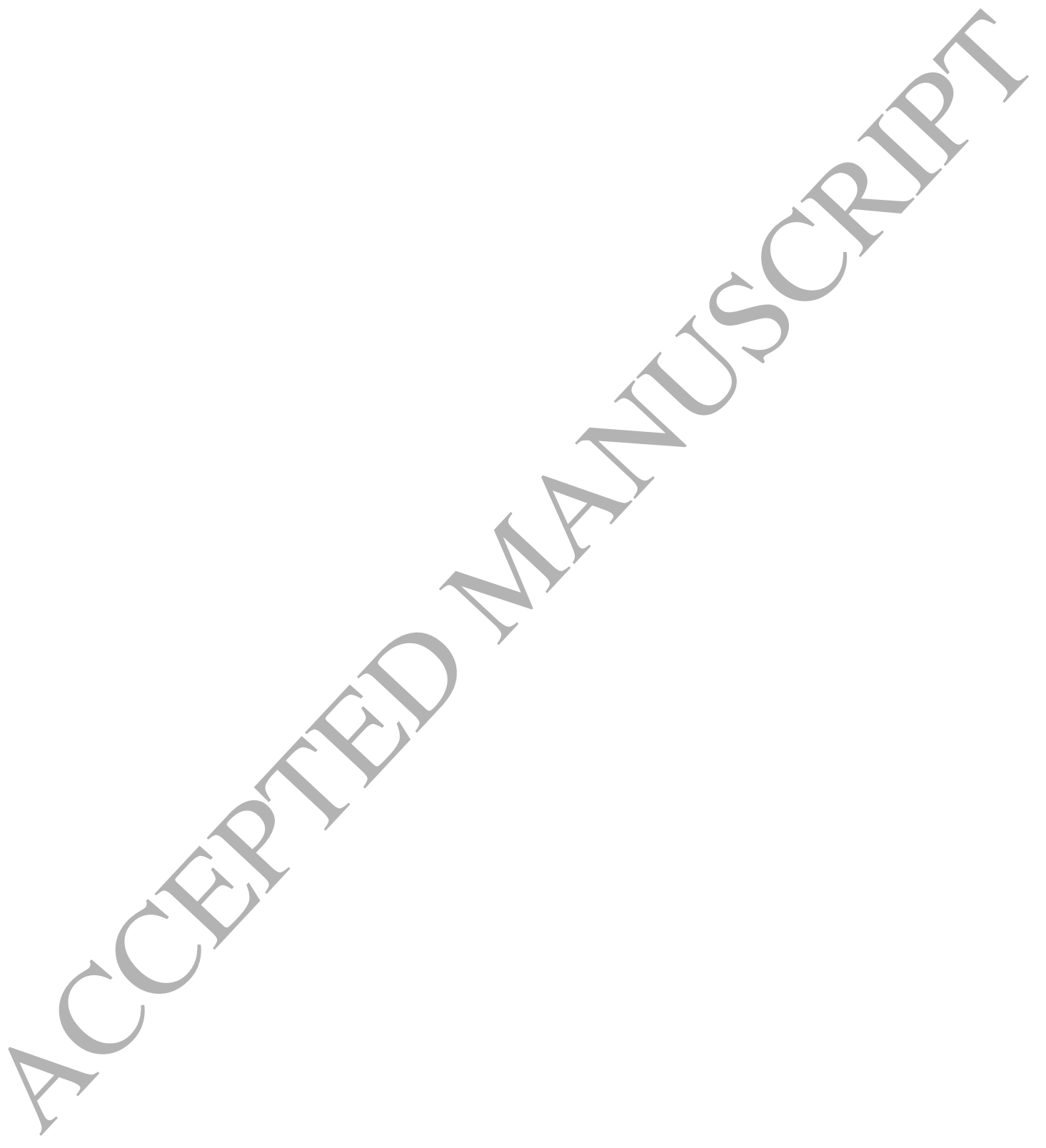




\title{
Heating system energy flexibility of low-energy residential buildings
}

\author{
Kyriaki Foteinaki ${ }^{\mathrm{a}, *}$, Rongling $\mathrm{Li}^{\mathrm{a}}$, Alfred Heller ${ }^{\mathrm{b}}$, Carsten Rode ${ }^{\mathrm{a}}$ \\ ${ }^{a}$ Department of Civil Engineering, Technical University of Denmark, Nils Koppels Allé Building 402, 2800 Kgs. Lyngby, Denmark \\ ${ }^{\mathrm{b}}$ NIRAS, Østre Havnegade 12, 9000 Aalborg, Danmark \\ * Corresponding author, e-mail: kyfote@byg.dtu.dk
}

\begin{abstract}
Energy flexibility is proposed as a cost-effective solution facilitating secure operation of the energy system while integrating large share of renewables. With strict building regulations in Denmark, newly built buildings are low-energy buildings. In order to identify the role of low-energy buildings in the energy system, we investigated the physical potential for flexibility and analysed the thermal storage capacity existing inherently in the structural mass. Two building types were studied: single-family house and apartment block. The aim is to quantify the energy that can be added to or curtailed from each building during a time period without compromising thermal comfort. Different scenarios (starting time and duration), building design characteristics and boundary conditions were studied. The findings showed that lowenergy buildings are highly robust and can remain autonomous for several hours. Although for individual buildings the available energy for curtailment is limited, if many buildings are aggregated energy flexibility becomes significant. The potential for storage in the thermal mass is considerable. The analysis presented high dependence of flexibility potential on boundary conditions (ambient temperature, solar radiation, internal gains) and underlined the importance of envelope insulation. Heat losses govern the potential for flexibility, while the walls' thermal mass has a secondary influence.
\end{abstract}

\section{Keywords}

Energy flexibility, Building thermal mass, Thermal energy storage, Low-energy building, Demand response

\section{Introduction}

It is anticipated that the share of renewable energy will constantly grow in the energy system. According to the European Council's climate and energy agreement from 2014, one of the three key targets for the year 2030 is that at least $27 \%$ of the European energy supply must derive from renewable energy sources (RES) [1]. Some countries have set even stricter energy frameworks; for example, Denmark aims to achieve an energy supply independent from fossil fuels by 2050 [2]. The fluctuating energy production from RES is the main challenge of power grid controllability and stability, 
hence stressing the need for balancing strategies. Among others, flexible energy systems have been proposed as a costeffective solution that would facilitate a secure operation of the energy system while integrating a large share of renewables. Methods for reducing peak loads and shifting demand have attracted great attention, such as developing appropriate markets and introducing new end use technologies for energy storage in the system [3]. Towards this direction, the building sector has great potential, as firstly buildings constitute $40 \%$ of the primary energy use in most European countries, and secondly the already existing large thermal mass in buildings can be utilized for thermal energy storage facilitating load shifting. The concept of energy flexibility of a building is not new, but has recently gained attention and was defined by IEA Energy in Buildings and Communities Program (EBC) Annex 67 "Energy Flexible Buildings" as "the ability to manage its demand and generation according to local climate conditions, user needs and grid requirements" [4]. Hence, energy flexible buildings will be able to respond to load control strategies determined by the requirements of the respective energy network [4].

Buildings consist of different types of shiftable loads requiring different control approaches, i.e. space heating and cooling, domestic hot water, charging of electric vehicles, etc. A number of studies have been performed on energy flexibility in buildings targeting one or more of the aforementioned/loads of a building. Indicatively, [5] modelled household load profiles in order to investigate the flexibility potential of domestic appliances, while [6] quantified the demand response flexibility of residential smart appliances, domestic hot water buffers and electric vehicles based on a pilot test in Belgium. The heat loads in a building can be exploited by utilizing different thermal energy storage technologies available, reviewed by [7]. Those most broadly used are the inherent thermal mass of the building structure ([8],[9]), with or without the integration of phase changing materials [10],[11], and additional units such as hot water tanks ([12],[13]).

In this study the structural thermal mass of buildings will be utilized as storage medium. The thermal mass is readily available in every building, requiring one extra investment, i.e. appropriate controllers of the heating system. In existing residential buildings most often such controllers are missing. Commercial buildings and new residential buildings frequently have the heating system connected to a building/home management system, which would have to be reprogrammed to be used for flexibility measures responding to an external signal. The characteristics of each building are decisive for the characterization of the flexibility potential [14]. In principle, the parameters that generically define the operation, energy needs and performance of a building will also set the framework and boundaries for the flexibility potential. The functional typology as well as the construction age and building type are among the most important parameters to be considered [14-16]. The functional typology, i.e. residential, commercial, etc., defines the type and 
intensity of loads available for flexibility and the occupancy profiles in general [17]. The construction age of the building, or renovation if relevant, defines first and foremost the properties of the thermal envelope and the installed systems $[14],[16],[18]$.

Research so far was mainly focused on typical examples of the building stock, namely old or moderately aged buildings, as cases studies to assess the flexibility potential such as [8],[19],[20],[21],[22]. In order for the concept of energy flexibility to be used on the energy system scale and across sectors, a portfolio with different potentials and dynamics should be available including building categories offering different options of services. Regarding the new generation of buildings, there are few studies that have studied and contrasted the potential of older to newer buildings [14-16], as well as [23] which studied a refurbished apartment of multi-family Mediterranean nZEB building, and [9] which studied a low-energy single-family house in France.

According to the Danish Building Regulation 2015 (BR15), for the new generation of buildings in Denmark "the total demand of the building for energy supply for heating, ventilation, cooling and domestic hot water must not exceed $30.0 \mathrm{kWh} / \mathrm{m}^{2}$ per year plus $1000 \mathrm{kWh}$ per year divided by the heated floor area" [24]. These buildings are well-insulated, airtight and may be heavy-weight, thus have large thermal storage capacity. In this study we analyse the thermal storage capacity of buildings which exists inherently in their structural mass. Two building types of different scales are studied, a single-family house and a multi-family apartment block. The aim is to quantify the energy that can be added to or curtailed from each building at a specific time period, namely the flexibility potential, under different scenarios in order to identify the role of low-energy buildings in the future energy system. The objective is to quantify the physically available energy flexibility of this type of buildings. The economic feasibility of the utilization of this flexibility is out of the scope of this study. Emphasis is given on building design characteristics and boundary conditions. This information could be provided to an aggregator/system operator enabling them to choose a suitable portfolio of buildings to participate in grid services facilitating flexibility in the operation of the energy system.

The structure of this paper is organized as follows. Section 2 explains the approach and presents the scenarios examined. Then the simulation models of the buildings are detailed, the boundary conditions are presented, followed by the building design parameter variations. In Section 3 the results of the simulations are presented and analysed, along with discussion of the outcomes. The main conclusions are summarized in the final section. 


\section{Methodology}

\subsection{Energy flexibility events}

In this section, the methodology for the evaluation of using structural thermal mass as storage medium is explained. Starting from a reference operation of the building, modulations of the temperature set-point of the heating system are performed. The inherent thermal mass is thus activated, either being charged after the air temperature set-point is increased, or being discharged after the air temperature set-point is decreased. In this study the reference operation is a typical thermostatic control with constant air temperature set-point at $22^{\circ} \mathrm{C}$, which is a typical desired indoor temperature in Danish households during the heating season. Two types of modulation from the reference operation are considered:

- Increased set-point to $24^{\circ} \mathrm{C}$ for a certain time duration, representing a scenario with abundance of renewable energy production in the energy system. In this case, heat supply in buildings can be increased and the additional heat introduced can be stored into the thermal mass (depicted in Figure 1, left). This type of modulation is further referred to as an upward flexibility event.

- Decreased set-point to $20^{\circ} \mathrm{C}$ for a certain time duration, representing a scenario with limited or no availability of renewable energy production in the energy system. In this case, heat supply in buildings can be curtailed or interrupted, imposing heat to be released from the thermal mass into the building (depicted in Figure 1, right). This type of modulation is further referred to as a downward flexibility event.

In all cases, thermal comfort of occupants ought not to be compromised. The limits of comfortable conditions ${ }^{1}$ of $22^{\circ} \mathrm{C} \pm 2{ }^{\circ} \mathrm{C}$ are chosen to be within the range of thermal comfort Category II "Normal level of expectations for new buildings" for heating season according to the standard EN/DS 15251 [25].

In related studies found in literature, the quantification of the flexibility potential is based on the response of a building to a signal from a specific energy system [9], [26]. The quantification is demonstrated during the operation of the building, using indicators such as energy, cost, $\mathrm{CO}_{2}$ emissions, etc., under specific system boundary conditions. In those cases, generalization and comparability of the results is limited. [20], [14] and [16] proposed and used a generic characterization method of the thermal response of the building, mostly relevant for the design phase of a building, and this is the approach also used in this work. Exemplary responses to upward and downward flexibility events are illustrated in Figure 1, together with the main flexibility parameters evaluated in this work, equivalent to those defined in [27].

\footnotetext{
${ }^{1}$ The standard EN/DS 15251 refers to operative temperature. However, the results from the simulations showed that in these buildings, the effect of cold surfaces is very limited, so air and operative temperatures have small differences, i.e. less than $0.5^{\circ} \mathrm{C}$ at all times. For the sake of clarity only indoor air temperature is presented in the graphs.
} 

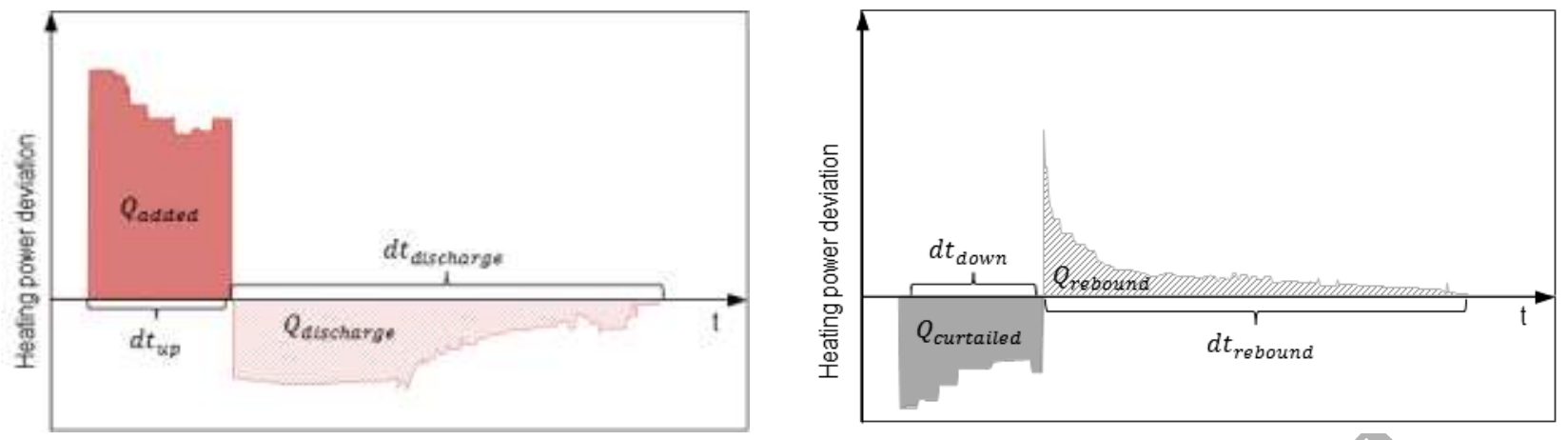

Figure 1: Exemplary responses to upward and downward flexibility events and main flexibility parameters

i) Added energy $\left(Q_{\text {added }}\right)$ : the amount of energy that is added to the building during the upward flexibility event. It is given by Equation (1): $Q_{a d d e d}=\int\left(q_{u p}-q_{\text {ref }}\right) d t_{u p}$ (1), where:

$d t_{u p}$ : the duration of upward flexibility event, when the temperature set-point is increased to $24^{\circ} \mathrm{C}$, $q_{u p}$ : the heating power during the upward flexibility event, $q_{\text {ref }}$ : the heating power during the reference operation of the building with the temperature set-point at $22^{\circ} \mathrm{C}$.

ii) Discharged energy $\left(Q_{\text {discharge }}\right)$ : the amount of energy that is utilized after being stored in the thermal mass of the building during the upward flexibility event. It is given by Equation (2):

$Q_{\text {discharge }}=\int\left(q_{\text {discharge }}-q_{\text {ref }}\right) d t_{\text {discharge }}$

(2), where:

$d t_{\text {discharge }}$ : the duration of time after the end of the upward flexibility event before the heating system returns to normal operation,

$q_{\text {discharge }}$ : the heating power during the discharging period.

iii) Curtailed energy ( $\left.Q_{\text {curtailed }}\right)$ : The amount of energy that is curtailed from the building during the downward flexibility event. It is given by Equation (3): $Q_{\text {curtailed }}=\int\left(q_{\text {down }}-q_{\text {ref }}\right) d t_{\text {down }}$ (3), where:

$d t_{\text {down }}$ : the duration of downward flexibility event, when the temperature set-point is decreased to $20^{\circ} \mathrm{C}$,

$q_{\text {down }}$ : the heating power during the downward flexibility event.

iv) Rebound energy $\left(Q_{\text {rebound }}\right)$ : the amount of energy that is additionally utilized by the building in order to return to the initial state after the downward flexibility event. It is given by Equation (4):

$Q_{\text {rebound }}=\int\left(q_{\text {rebound }}-q_{\text {ref }}\right) d t_{\text {rebound }}(4)$, where:

$d t_{\text {rebound }}$ : The duration of time after the end of the downward flexibility event before the heating system returns to normal operation,

$q_{\text {rebound }}:$ the heating power during the rebound effect period. 
Both $Q[k W h]$ and $q[W]$ refer to the net energy/heating power of the heat emission system, not the entire heating system, in order to avoid dependencies on the choice of the system, its configuration and the energy carrier.

By definition, the available energy that can be added to or curtailed from a building during a specific flexibility event depends on multiple parameters and is inevitably time-dependent. As the storage medium is the structural mass of the building, the characteristics of the building are of vital importance, including thermal properties, which are presented in Section 2.4. The quantification is determined during a specific flexibility event. The duration and starting time of the event are main characteristics, thus their impact is assessed. In this study, the following flexibility events are investigated:

- Flexibility events with duration 2 hours, 4 hours, 6 hours, 8 hours, 12 hours, 16 hours, and 24 hours.

- Flexibility events with starting time at midnight (00:00), early morning (06:00), midday (12:00) and evening (18:00).

Structural thermal mass, in contrast to other storage media, is particularly sensitive to boundary conditions. Ambient weather conditions are examined in this study (Section 2.3) including solar radiation and ambient air temperature.

\subsection{Building models}

The building regulations become progressively stricter on minimizing heat losses and increasing efficiency of heating, cooling and ventilation systems in buildings. The Danish Building Regulation 2015 (BR15) [24] introduced the new generation of buildings that will participate in the energy system. Two building types according to the BR15 standard are chosen to be studied; a single-family house (Figure 2) and an apartment block (Figure 3), both representing typical Danish buildings of its type. The design, construction and materials chosen are in accordance with BR15, the Danish Building Research Institute (SBi) Guidelines 'Energy Demand for Buildings' [28] and some details are supplemented by TABULA Webtool [18]. Both building types are heavy-weight and well insulated.

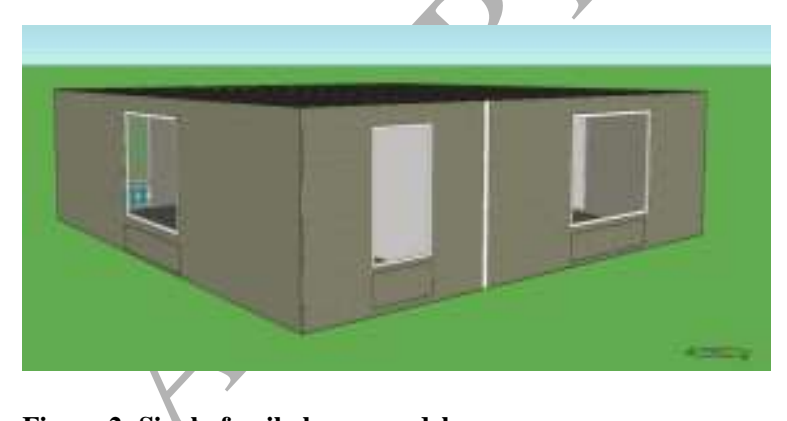

Figure 2: Single-family house model

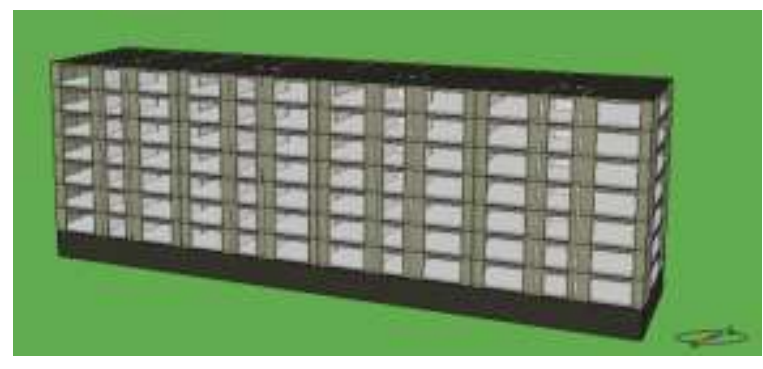

Figure 3: Apartment block model

Table 1 and Table 2 present the properties of the main construction components of the single-family house and apartment block, respectively. The properties of the materials used are shown in Table 3. 
Table 1: Properties of main components for single-family house

\begin{tabular}{|c|c|c|c|c|}
\hline Components & Thickness [mm] & $\begin{array}{l}\text { U-value } \\
{\left[\mathbf{W} /\left(\mathbf{m}^{2} \cdot \mathbf{K}\right)\right]}\end{array}$ & $\begin{array}{l}\text { Surface } \\
{\left[\text { net } \mathbf{m}^{2}\right]}\end{array}$ & Materials \\
\hline External wall & 448 & 0.138 & 109 & $\begin{array}{l}\text { Aerated concrete }(100 \mathrm{~mm}) \\
\text { Insulation class } 38(240 \mathrm{~mm}) \\
\text { Brick }(108 \mathrm{~mm})\end{array}$ \\
\hline Internal load-bearing wall & 150 & 4.082 & 37 & Concrete \\
\hline Internal non-bearing wall & 100 & 1.349 & 97 & Aerated concrete \\
\hline Roof & 567 & 0.077 & 149 & $\begin{array}{l}\text { Plaster board }(26 \mathrm{~mm}) \\
\text { Scattered wooden boards }(22 \mathrm{~mm}) \\
\text { Insulation class } 38(460 \mathrm{~mm}) \\
\text { Roof tiles }(59 \mathrm{~mm})\end{array}$ \\
\hline Floor & 472 & 0.105 & 149 & $\begin{array}{l}\text { Oak planks }(22 \mathrm{~mm}) \\
\text { Concrete }(100 \mathrm{~mm}) \\
\text { Insulation class } 38(350 \mathrm{~mm})\end{array}$ \\
\hline \multicolumn{5}{|c|}{ Table 2: Properties of main components for apartment block } \\
\hline Components & Thickness [mm] & $\begin{array}{l}\text { U-value } \\
{\left[\mathbf{W} /\left(\mathbf{m}^{2} \cdot \mathbf{K}\right)\right]}\end{array}$ & & Materials \\
\hline External wall & 448 & 0.138 & & $\begin{array}{l}\text { Aerated concrete }(100 \mathrm{~mm}) \\
\text { Insulation class } 38(240 \mathrm{~mm}) \\
\text { Brick }(108 \mathrm{~mm})\end{array}$ \\
\hline Internal load-bearing wall & 200 & 3.704 & & Concrete \\
\hline Internal non-bearing wall & 100 & 1.349 & 21 & Aerated concrete \\
\hline Roof & 670 & 0.092 & 980 & $\begin{array}{l}\text { Hollow core concrete }(270 \mathrm{~mm}) \\
\text { Insulation class } 38(400 \mathrm{~mm})\end{array}$ \\
\hline Floor towards ground & 470 & & 980 & $\begin{array}{l}\text { Concrete }(120 \mathrm{~mm}) \\
\text { Insulation class } 38(350 \mathrm{~mm})\end{array}$ \\
\hline Floor/ceiling decks & 407 & & 6860 & $\begin{array}{l}\text { Oak planks }(14 \mathrm{~mm}) \\
\text { Concrete }(80 \mathrm{~mm}) \\
\text { Insulation class } 38(93 \mathrm{~mm}) \\
\text { Concrete }(220 \mathrm{~mm})\end{array}$ \\
\hline Windows & 3 pan & 0.900 & 1408 & - \\
\hline
\end{tabular}

Table 3: Material properties

\begin{tabular}{lccc}
\hline Material properties & $\begin{array}{c}\text { Thermal conductivity } \\
{[\mathbf{W} /(\mathbf{m} \cdot \mathbf{K})]}\end{array}$ & $\begin{array}{c}\text { Density } \\
{\left[\mathbf{k g} / \mathbf{m}^{3}\right]}\end{array}$ & $\begin{array}{c}\text { Specific heat } \\
{[\mathbf{J} /(\mathbf{k g} \cdot \mathbf{K})]}\end{array}$ \\
\hline Aerated concrete & 0.175 & 650 & 900 \\
Concrete & 2.000 & 2300 & 900 \\
Brick & 0.730 & 1800 & 840 \\
Insulation class 38 & 0.038 & 20 & 750 \\
Gypsum board & 0.220 & 970 & 2000 \\
Oak planks & 0.170 & 750 & 800 \\
Roof tiles & 0.840 & 1900 & 900 \\
Hollow core concrete $(40 \%$ hollow core) & 1.600 & 1380 & 1300 \\
Furniture & 0.130 & 1000 & \\
\hline
\end{tabular}


The single-family house has a net heated floor area of $149 \mathrm{~m}^{2}$ and envelope area per volume $0.998 \mathrm{~m}^{2} / \mathrm{m}^{3} . \mathrm{The}$ effective thermal capacity is calculated $60 \mathrm{MJ} / \mathrm{K}$ (see Appendix for the detailed calculation) and the heat losses, which are received as output from the simulation tool, are $101 \mathrm{~W} / \mathrm{K}$. The ratio of those two leads to a time constant of 165 hours. The single-family house model is divided into two thermal zones: a primarily day-occupied zone, i.e. living room, kitchen, and a primarily night-occupied zone, i.e. bedrooms. The windows comprise $22.5 \%$ of the heated floor area and are distributed $41 \%$ south, $26 \%$ north and $33 \%$ east/west following the reference single-family house of BR 15 .

The apartment block has a net heated floor area of $6272 \mathrm{~m}^{2}$ and envelope area per volume $0.265 \mathrm{~m}^{2} / \mathrm{m}^{3}$. The effective thermal capacity is calculated $2908 \mathrm{MJ} / \mathrm{K}$ and the heat losses are $3084 \mathrm{~W} / \mathrm{K}$, leading to a time constant of 262 hours. The building has 7 floors and an unheated basement, which is assumed to be around $15^{\circ} \mathrm{C}$, maintained from heat losses of hot water pipes. Each floor has 8 apartments with the same floor area of $112 \mathrm{~m}^{2}$ each, and 4 staircases with the same floor area of $21 \mathrm{~m}^{2}$ each. The windows comprise $22.5 \%$ of the heated floor area and are distributed $52 \%$ south, $37 \%$ north and $11 \%$ east/west. The apartment block was modelled as one thermal zone per apartment and one thermal zone per staircase, using adequate zone multiplication of the zones that present similar thermal behaviour.

In this study only space heating is considered, as the objective of the work is to evaluate the storage capacity of the inherent thermal mass of the building structure. The heat emission system in both buildings is low temperature water radiators dimensioned according to the standard DS 418 [29] for indoor temperature $20^{\circ} \mathrm{C}$ and outdoor temperature $12^{\circ} \mathrm{C}$, using an over-dimensioning factor of $15 \%$. The maximum heating power of the radiators is $21 \mathrm{~W} / \mathrm{m}^{2}$ heated floor area for the single-family house and $14 \mathrm{~W} / \mathrm{m}^{2}$ heated floor area for the apartment block, both controlled with proportional controller. The supply water temperature to the system is $45^{\circ} \mathrm{C}$. Mechanical ventilation is installed in the buildings with constant air volume of $0.3 \mathrm{l} / \mathrm{s}$ per $\mathrm{m}^{2}$ of heated floor area, using heat recovery of $80 \%$ efficiency for the single-family

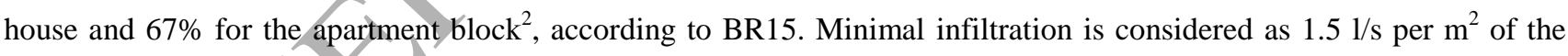
heated floor area at a pressure differential of $50 \mathrm{~Pa}$. A very low effect of structural thermal bridging is considered, about $0.02 \mathrm{~W} / \mathrm{K}$ per $\mathrm{m}^{2}$ envelope. Internal masses are included in the models to represent furniture, with a total area of $26 \mathrm{~m}^{2}$ in the single-family house and $1120 \mathrm{~m}^{2}$ in the apartment block. The furniture is assumed to have the properties shown in Table 3 with thickness of $10 \mathrm{~mm}$ and convective heat transfer coefficient of $6 \mathrm{~W} / \mathrm{m}^{2} \mathrm{~K}$. The ground model is calculated in the simulation tool according to the standard ISO 13370 [30].

\footnotetext{
${ }^{2}$ When this study was finished, the new building regulation 2018 (BR18) was published. The only difference in the new regulation is the efficiency of heat recovery of the ventilation system for apartment blocks, which, in the new code, is the same as the single-family house, namely $80 \%$. If the simulations were run according to BR18, the only difference in the results would be the heating demand for the apartment block, which would slightly decrease.
} 
The simulations are performed with the building performance simulation software IDA Indoor Climate and Energy, version 4.7 [31]. It is a dynamic whole-building simulation tool based on symbolic equations stated in Neutral Modeling Format (NMF) and has undergone several validation tests [32-36]. The building, systems, controls, network airflow, etc. are simulated in an integrated way and the time-step varies dynamically during runtime to automatically adapt to the nature of the problem.

\subsection{Boundary conditions}

The performance of the structural thermal mass as a storage medium is highly dependent on boundary conditions. Regarding the ambient weather conditions, in this study representative days of the heating season in Denmark are chosen for cold, moderate and warm days. The weather data used are from the Danish Meteorological Institute representing the Danish Design Reference Year [37]. Solar radiation is also considered, so simulations run both with cloudy and clear sky. Figure 4 presents the ambient air temperature and global solar irradiance used in the simulations for cold, moderate and warm days with cloudy and clear sky. Each simulation runs for four days; one day prior to the day when set-point modulation is performed and two days after that. Before each simulation, a dynamic start-up phase of one month is simulated in order to eliminate the effect of initial conditions.
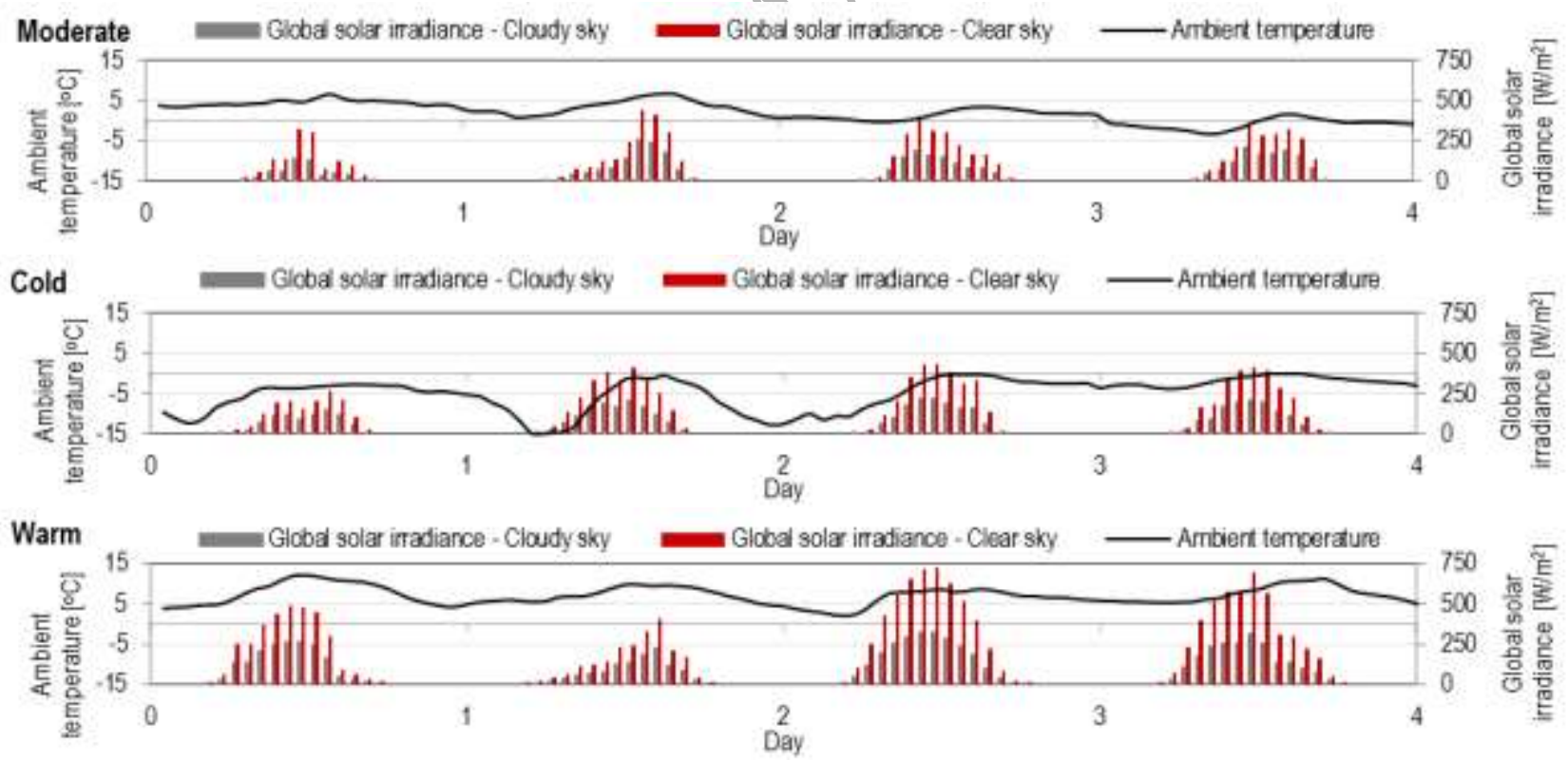

Figure 4: Ambient air temperature and global solar irradiance for representative moderate (top), cold (middle) and warm (bottom) days of the heating season with cloudy and clear sky

The schedules for the internal gains are set according to the standard DS/EN ISO 13790:2008 Table G.8 [38], which are different for primarily day or night occupied zones. The internal heat gains include heat emitted from lighting, equipment and occupants. In the single-family house there are two thermal zones, each with the respective schedule for 
internal gains, while in the apartment block, which is modelled as one thermal zone per apartment, two components of internal gains are used in the same zone, one for each schedule. Figure 5 shows the ratio of internal gains compared to the maximum internal gains for every hour of the day. The total heat flow rate from internal gains is $5 \mathrm{~W} / \mathrm{m}^{2}$, which is lower than the one indicated by the standard [38], but it is adjusted in order to meet the average Danish national values [28].

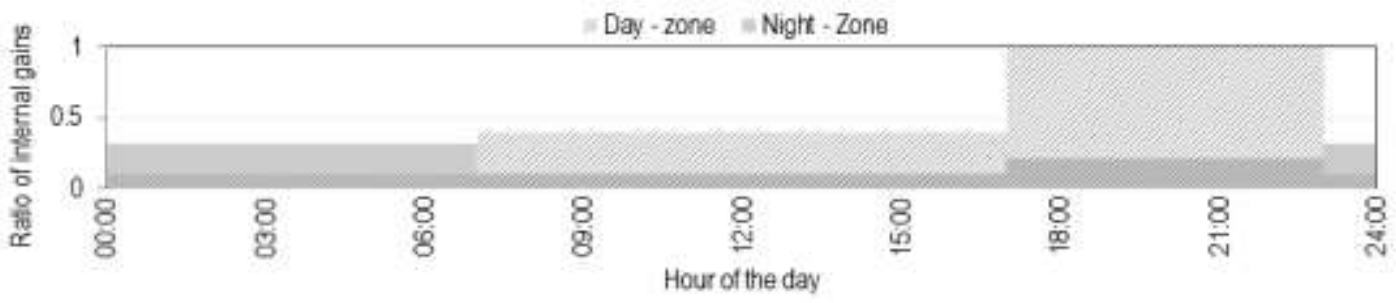

Figure 5: Schedules for internal gains in the primarily day-occupied and night-occupied zone

\subsection{Building design parameter variations}

Since the storage medium is the structural thermal mass, the design parameters of external and internal walls are influential parameters in the quantification of the indicator, as also underlined by [9],[14],[20],[39]. Certain parameters are chosen to be studied, in order to examine the relative impact of each design parameter choice. The range of each parameter used is presented in Table 4. The baseline building case is presented with bold font for each parameter.

Table 4: Building design parameter variations

\begin{tabular}{llllll}
\hline Parameter & \multicolumn{5}{c}{ Range } \\
\hline Window U-Value [W/m $\left.{ }^{2} \mathrm{~K}\right]$ & 1.8 & 1.5 & 1.2 & $\mathbf{0 . 9}$ & 0.6 \\
External Wall Insulation Thickness [cm] & 16 & 20 & $\mathbf{2 4}$ & 28 & 32 \\
External Wall Concrete Thickness $^{3}[\mathrm{~cm}]$ & $0^{4}$ & 5 & $\mathbf{1 0}$ & 15 & 20 \\
Internal $^{5}$ Wall Concrete Thickness [cm] & $5^{6}$ & 10 & $\mathbf{1 5}$ & $\mathbf{2 0}$ & 25 \\
Windows / Heated Floor Area Ratio [-] $^{7}$ & $12.5 \%$ & $17.5 \%$ & $\mathbf{2 2 . 5 \%}$ & $27.5 \%$ & $32.5 \%$ \\
\hline
\end{tabular}

The aim of the parameter study is to examine two properties of the thermal mass: the heat losses to the ambient and the thermal capacity of the thermal mass, in order to contrast their contribution to the amount of energy that can be added to or curtailed from the buildings during flexibility events. To examine the effect of the heat losses, the window U-value and the externar wall insulation thickness are studied while keeping the thermal capacity of thermal mass unaltered. To

\footnotetext{
${ }^{3}$ Inside of the insulation layer

${ }^{4}$ The external wall with $0 \mathrm{~cm}$ concrete represents a wall with thermal insulation on the interior surface.

${ }^{5}$ Internal load-bearing walls are considered in the variation

${ }^{6}$ Buildings with this variation belong to the category of semi-light buildings according to the Danish Building Research Institute (SBi) Guidelines

'Energy Demand for Buildings' [27].

${ }^{7}$ The value for the baseline building case for the Internal Wall Concrete Thickness is $15 \mathrm{~cm}$ for the single-family house and $20 \mathrm{~cm}$ for the apartment block.
} 
study the effect of the thermal capacity, the external wall concrete thickness is adjusted, with the insulation thickness being adjusted accordingly to ensure that the heat losses to the ambient remained unaltered. Similarly, the effect of the thermal capacity of internal thermal mass is studied with variations of the internal load-bearing wall concrete thickness. When changing the window to heated floor area ratio, the effect is rather complicated as both the capacity of thermal mass and the heat losses change, while simultaneously the solar gains are affected.

\section{Results and Discussion}

In this section, the results of the simulations are presented and discussed. In Section 3.1 , the operation of the buildings is presented under reference conditions with the temperature set-point constantly at $22^{\circ} \mathrm{C}$, in order to briefly demonstrate the energy performance of this type of buildings and provide a better insight of the respective thermal behaviour. In Section 3.2.1 the results for the chosen base case flexibility events implemented to the buildings are presented, one upward and one downward, and the thermal behaviour of the buildings is analysed. Flexibility events with different duration and start time are presented in Section 3.2.2. The analysis of the impact of dynamic boundary conditions is detailed in Section 3.3. In Section 3.4, the influence of building design parameters on energy flexibility is presented.

\subsection{Heating demand under reference operation}

This section presents the reference operation of the buildings with constant temperature set-point at $22^{\circ} \mathrm{C}$ during the heating season (November-March). The peak demand for space heating for the single-family house was $2.5 \mathrm{~kW}(16.8$ $\mathrm{W} / \mathrm{m}^{2}$ ) and the space heating energy use was $21 \mathrm{kWh} / \mathrm{m}^{2}$ net heated floor area. Figure 6 presents the heat introduced into the house, categorized into heat coming from the heating system, internal gains (occupants, equipment and lighting) and solar gains. For the single-family house $48 \%$ of the heating needs were supplied from the heating system. The other half came from solar and internal heat gains, which contributed with $11 \%$ and $41 \%$ respectively. This distribution should be taken into consideration when implementing flexibility events to new buildings. On the one hand, the thermal comfort would be less sensitive to any variations in the heat supply, while on the other hand, the influence of uncontrollable factors such as solar and internal gains should be taken into consideration. 

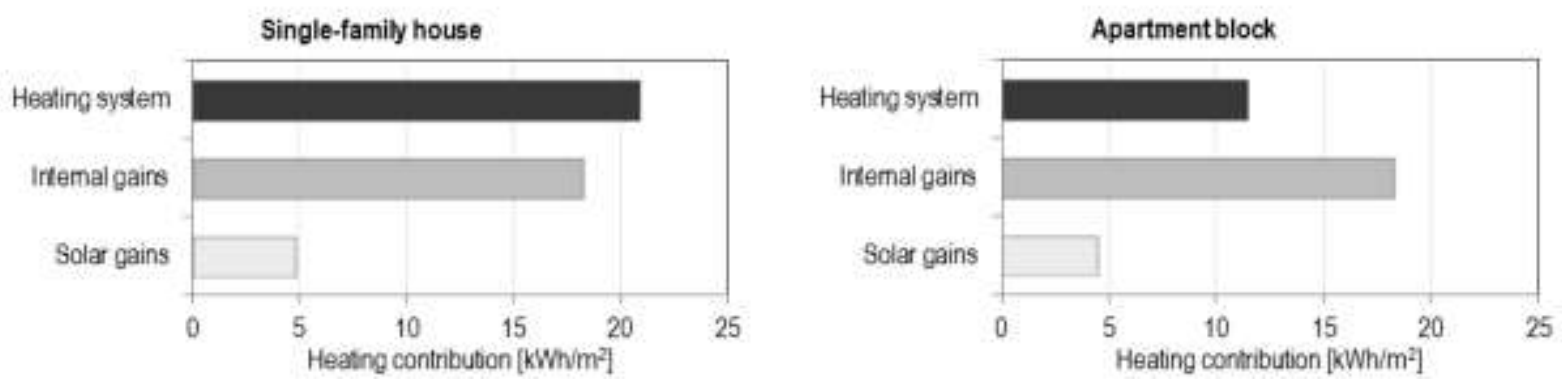

Figure 6: Analysis of heating contribution during reference operation with temperature set-point at $22^{\circ} \mathrm{C}$ for the single-family house (left) and the apartment block (right)

For the reference operation of the apartment block, the peak demand for space heating was $82 \mathrm{~kW}\left(13.1 \mathrm{~W} / \mathrm{m}^{2}\right)$ and the space heating energy use was $12 \mathrm{kWh} / \mathrm{m}^{2}$ net heated floor area. The apartment block had lower energy use for space heating in comparison to the single-family house, since the ratio of the envelope area per volume is significantly lower. As depicted in Figure 6, the heat sources in the apartment block had partly different contributions compared to those of the single-family house. The internal gains in the apartment were of the same schedule and intensity as in the singlefamily house, but the percentage contribution was higher, covering a total of $53 \%$ of the building space heating needs. The solar gains were marginally lower in the apartment than in the single-family house, but the percentage contribution was a little higher (13\%). Thereby, the contribution of the heating system was limited to $34 \%$ of the total heating needs of the apartment.

\subsection{Energy flexibility}

\subsubsection{Base case energy flexibility}

In this section, two base case flexibility events are presented, one upward and one downward. The implemented events started at 06:00, had duration of 8 hours and were performed under ambient weather conditions of moderate winter days in Denmark with cloudy sky as depicted in Figure 4 (top). Consistent colour code is used for the figures as follows: red refers to upward flexibility events, grey to downward flexibility events, and blue to the reference operation. Figure 7 and Figure 8 present results of the single-family house and the apartment block, respectively, with the heating power (top) and indoor air temperature (bottom) during the base case flexibility events. During Day 1, the buildings are under the reference operation and the heating power is depicted with a solid blue curve. In Day 2, the modulations of the base case flexibility events are implemented, with the respective added/curtailed heating power being highlighted in the figures, and the effects are observed onwards. 


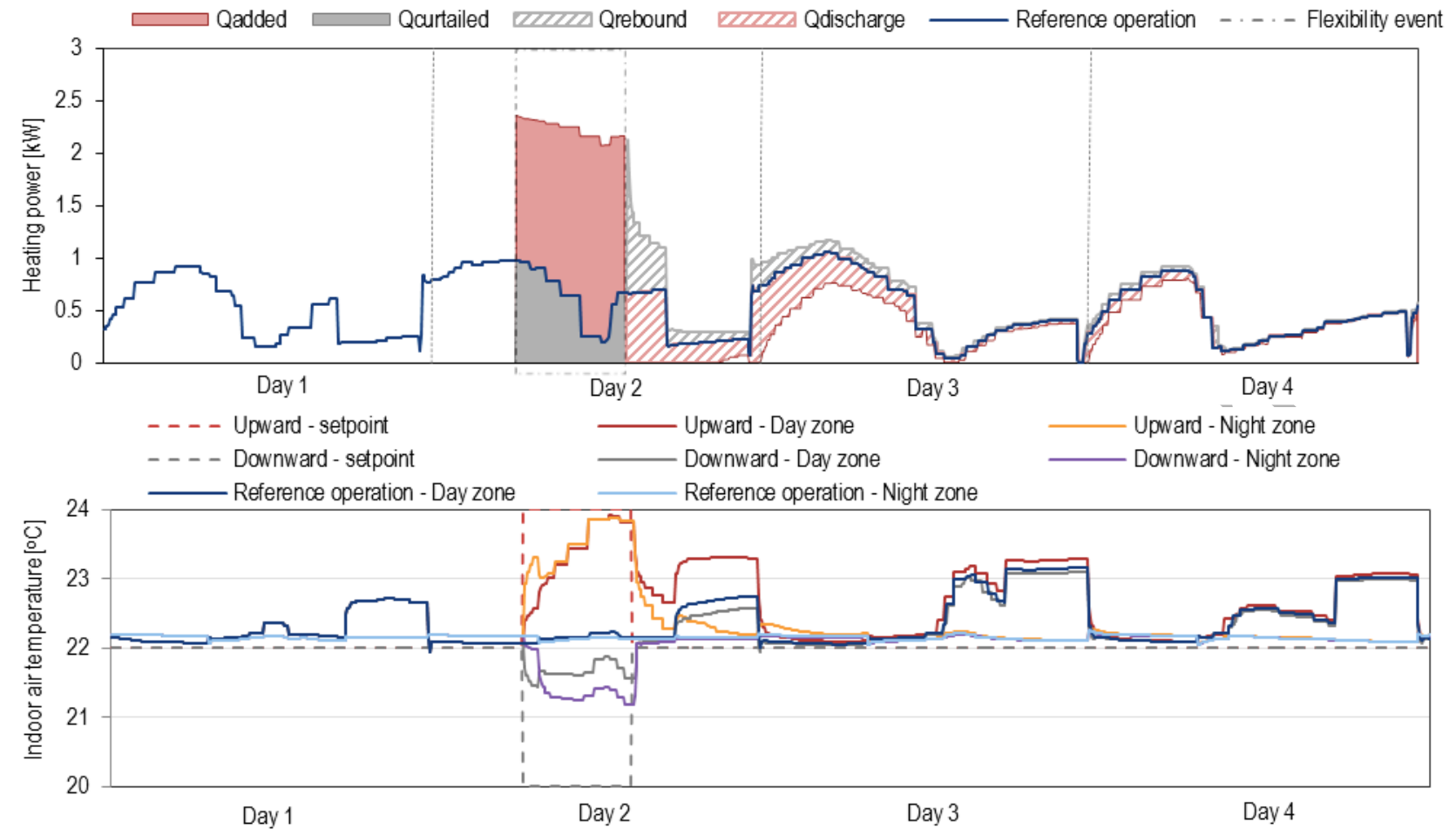

Figure 7: Heating power (top) and indoor air temperature (bottom) during base case flexibility events for the single-family house

For the single-family house, during the upward flexibility event, there was a considerable increase in heating power, which was followed by 10 hours during which the heat supply was eliminated. For approximately 40 hours after the event, the energy supply from the heating system was lower than the one of the reference operation, since energy was discharged from the thermal mass. For the downward flexibility event, the heat supply was interrupted completely during the event. The event was followed by a peak, which lasted approximately 3 hours. It was expected that utilization of flexibility results in increased peaks for the heating system. Although it was not the focus of this study, implications on the heating system, such as the new heating peaks created, should be taken into consideration when utilizing the flexibility [40]. For approximately 20 hours after the event, the energy use was slightly higher than the one of the reference operation (rebound effect). The bottom graph of Figure 7 shows the indoor air temperatures of the two zones. The temperature set-points are presented with the dashed lines. Regarding the upward event, the set-point of $24^{\circ} \mathrm{C}$ was reached after approximately 5 hours in both zones. When decreasing the set-point to $20^{\circ} \mathrm{C}$, the temperature decrease was rather slow. Within the 8 hour duration of the event, the temperature dropped to minima of $21.5^{\circ} \mathrm{C}$ and $21.3^{\circ} \mathrm{C}$ in the day and night zone, respectively. In all cases, the impact of the internal gains was apparent; every day in the evening when internal gains peaked in the day zone, the air temperature increased by almost $1{ }^{\circ} \mathrm{C}$, while the energy use was relatively low. It can be also noticed that every day around midday the energy use decreased due to the existence of solar gains, even on a cloudy day. 

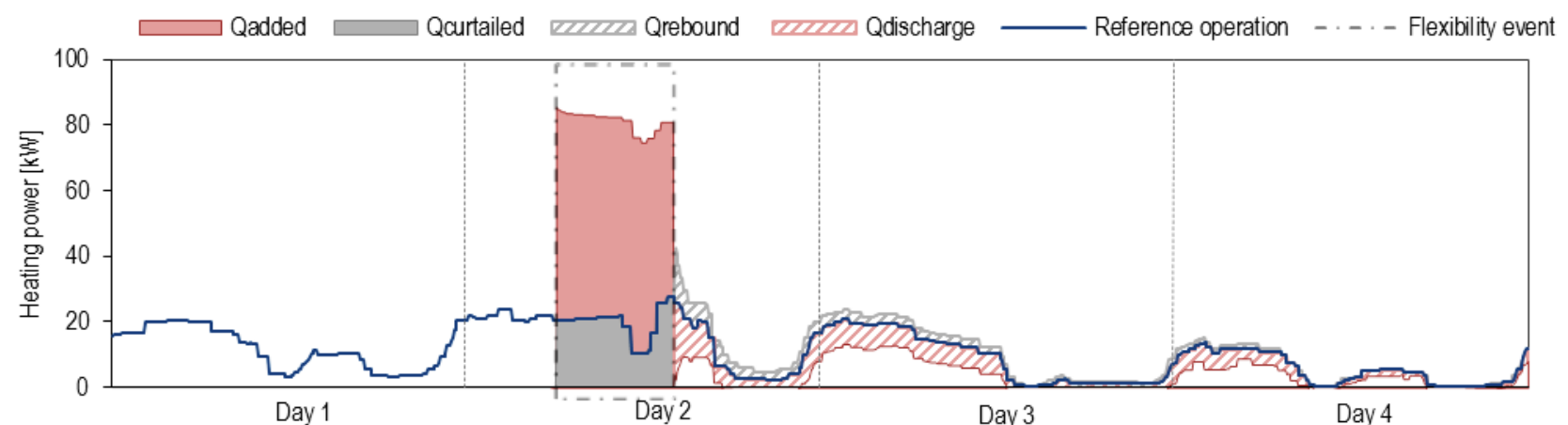

- - - - Upward - setpoint

- - - - Downward - setpoint

- Upward - Coldest apartment

Day 3

Day 4

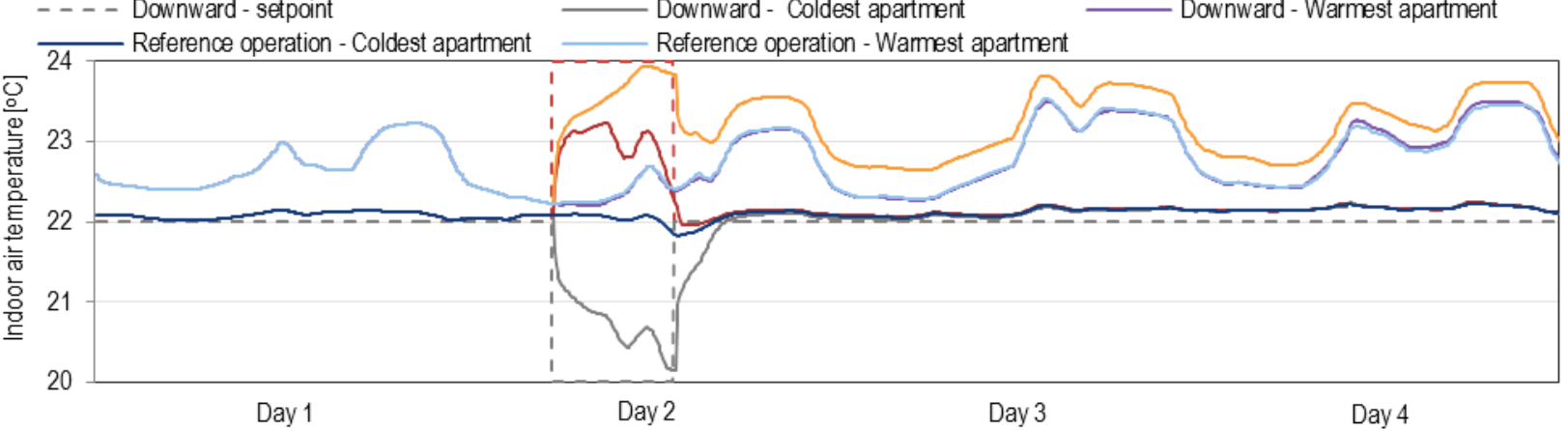

Figure 8: Heating power (top) and indoor air temperature (bottom) during base case flexibility events for the apartment block

Regarding the apartment block (Figure 8), the thermal behayiour was similar to the one of the single-family house.

The indoor air temperatures depicted were those from the apartments considered as critical, with a middle apartment on the $3^{\text {rd }}$ floor being the warmest and a top corner apartment being the coldest. The two apartments have considerably different thermal environments. The warmest apartment was insignificantly affected by the changes in the set-points, thereby any potential changes in the heat supply. It can be also noticed that the temperature in this apartment was constantly higher than the set-point of $22^{\circ} \mathrm{C}$. In the apartment block there are more apartments of the warmer type, so the apartment block is mostly affected by this behaviour. This explains why the peak created due to the rebound effect after the downward flexibility event was relatively small. This thermal behaviour indicates that overheating might be an issue for this type of apartments, especially under milder ambient weather conditions. In the coldest apartment, the temperature decreased at a faster pace compared to the single-family house, dropping close to $20^{\circ} \mathrm{C}$ at the end of the downward flexibility event. On the other hand, during the upward flexibility event, the indoor air temperature did not manage to increase higher than $23.2^{\circ} \mathrm{C}$. An important diversity between the thermal behaviour of the two apartments is noted. Since the same modulation was implemented for the entire apartment block, the thermal comfort of all apartments needed to be considered. Another approach could be to apply different flexibility modulations in different types of apartments, which could lead to higher potential for flexibility, but this was not implemented in this study. 
The total amount of energy supplied for the four days to the single-family house was $751 \mathrm{Wh} / \mathrm{m}^{2}$ for the reference operation, $771 \mathrm{Wh} / \mathrm{m}^{2}$ for the upward flexibility and $751 \mathrm{Wh} / \mathrm{m}^{2}$ for the downward flexibility. For the apartment block the total energy supplied was $339 \mathrm{Wh} / \mathrm{m}^{2}$ for the reference operation, $375 \mathrm{Wh} / \mathrm{m}^{2}$ for the upward flexibility and $324 \mathrm{Wh} / \mathrm{m}^{2}$ for the downward flexibility. In this case the upward flexibility events led to increased energy use, namely $2.7 \%$ for the single-family house and $10.6 \%$ for the apartment block, while the downward flexibility events led to the same energy use for the single-family house, but decreased energy use by $4.4 \%$ for the apartment block. The apartment block used considerably less energy per square meter than the single-family house, as the ratio of the envelope area per volume of the apartment block $\left(0.265 \mathrm{~m}^{2} / \mathrm{m}^{3}\right)$ is considerably lower than the one for the single-family house $\left(0.998 \mathrm{~m}^{2} / \mathrm{m}^{3}\right)$. The $\mathrm{small}$ energy needs together with the small heat loss are the reasons why the apartment block performs as an efficient energy storage body.

Summing the energy that was additionally introduced $\left(Q_{\text {added }}\right)$ or curtailed $\left(Q_{\text {curtailed }}\right)$, during the flexibility events the results are presented with a bar in Figure 9, with red being the additional energy and grey being the curtailed energy.
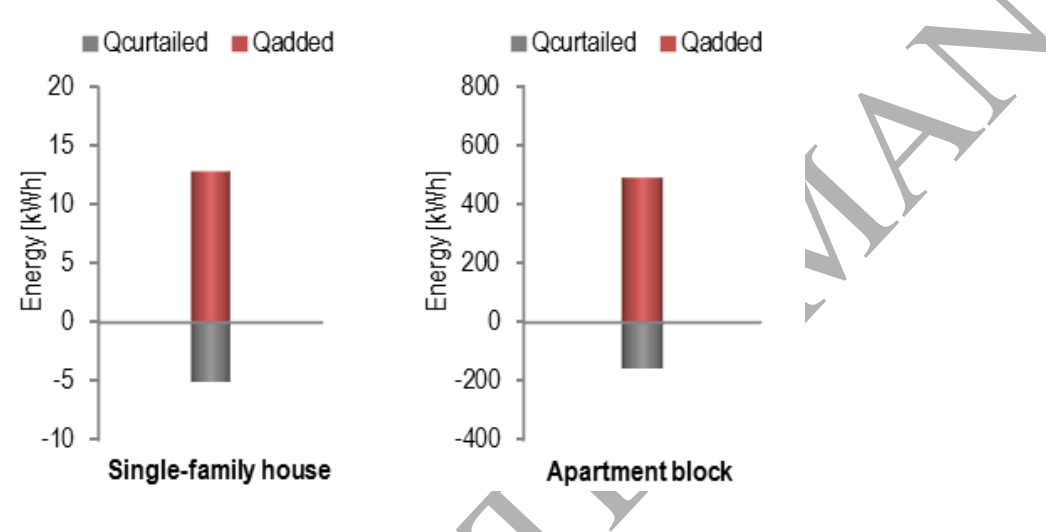

Figure 9: Energy added/curtailed during upward/downward flexibility events for the single-family house (left) and the apartment block (right)

In the single-family house (Figure 9 , left) $13 \mathrm{kWh}\left(87 \mathrm{Wh} / \mathrm{m}^{2}\right)$ were additionally added during 8 hours, while $5 \mathrm{kWh}$ $\left(36 \mathrm{Wh} / \mathrm{m}^{2}\right)$ were curtailed during 8 hours. In the apartment block (Figure 9, right) $492 \mathrm{kWh}\left(78 \mathrm{Wh} / \mathrm{m}^{2}\right) \mathrm{were}$ additionally added during 8 hours, while $156 \mathrm{kWh}\left(25 \mathrm{Wh} / \mathrm{m}^{2}\right)$ were curtailed during 8 hours. A clear asymmetry between the added and the curtailed energy is noticed in both buildings. As previously shown, the heat supply was eliminated during the downward event. This means that the amount of available energy to be curtailed is determined by the heating need of the reference scenario $\left(22^{\circ} \mathrm{C}\right)$. Hence, the maximum energy available for curtailment is highly related to the heating demand of the buildings during normal operation; thereby, for low-energy buildings the potential for curtailment is limited. On the other hand, the maximum energy that can be added is limited either by the capacity of the heating system or by the upper thermal comfort limit, in this study $24^{\circ} \mathrm{C}$. 
As already mentioned, the low heating demand restricts the potential for curtailment, hence downward energy flexibility. However, the indoor temperature does not change fast. If instead of modulating the set-points, the heat supply is completely interrupted, the single-family house maintains the temperature above $20^{\circ} \mathrm{C}$ for more than 48 hours, while the apartment block keeps the temperature above $20^{\circ} \mathrm{C}$ for 20 hours in the coldest apartments and more than 3 days in the rest of the apartments. The buildings are, thereby, robust and can be independent for a long period of time without jeopardising the thermal comfort of the occupants. These long hours of autonomy allow the system operators to exploit the independence of their operation. Although the low energy needs limit the energy available for curtailment in each building individually, aggregating similar type of buildings to a large number, the amount of energy becomes considerable. The potential for upward flexibility appeared greater, enabling the energy system to use these buildings as heat sinks if needed or implementing preheating to the buildings if their autonomy needs to be prolonged. The different thermal behaviour with regards to energy flexible operation of this category of buildings in comparison to other categories of buildings broadens the portfolio of options for system operators when flexibility is needed in the system.

\subsubsection{Energy flexibility of events with various duration and start time}

The duration and start time of the flexibility event are parameters that are to be decided according to the system's needs every time that a flexibility event is to be implemented. Simulations were performed first varying the duration of the flexibility events between $2,4,6,8,12,16$ and 24 hours (each of them starting at 06:00), and then varying the starting time, with events starting at 00:00, 06:00, 12:00 and 18:00 (with a duration of 8 hours each of them). The rest of the boundary conditions remained as the base case flexibility events. Figure 10 and Figure 11 present the results of the simulations performed for the single-family house and the apartment block, respectively. The base case flexibility events are outlined with black colour.
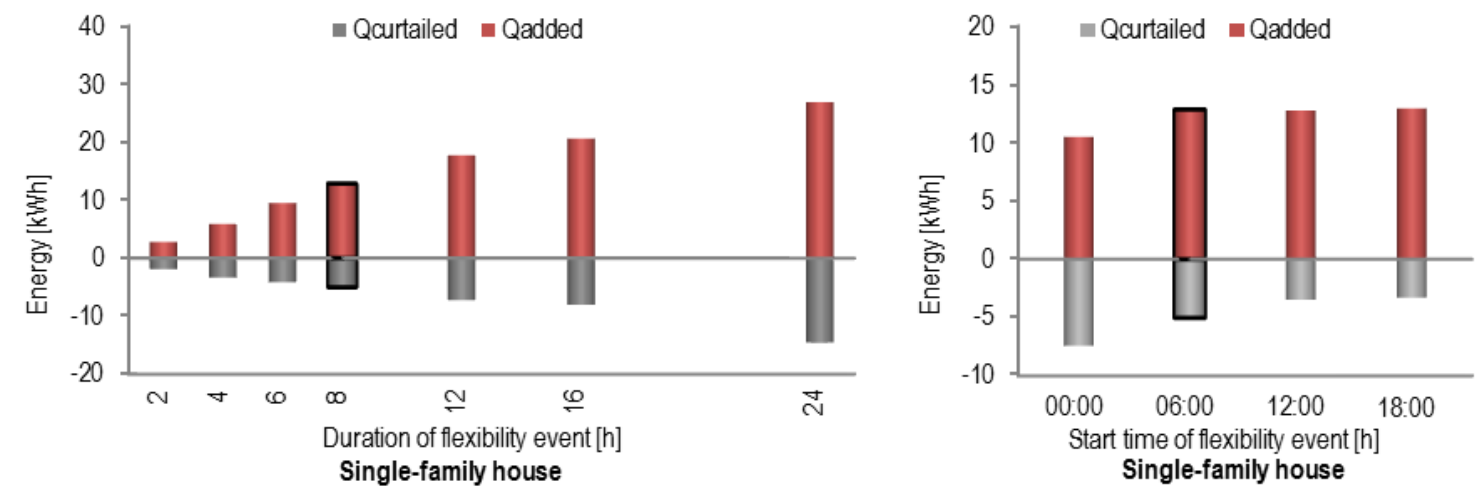

Figure 10: Energy added/curtailed during upward/downward flexibility events with different durations (left) and different starting time (right) for the single-family house 

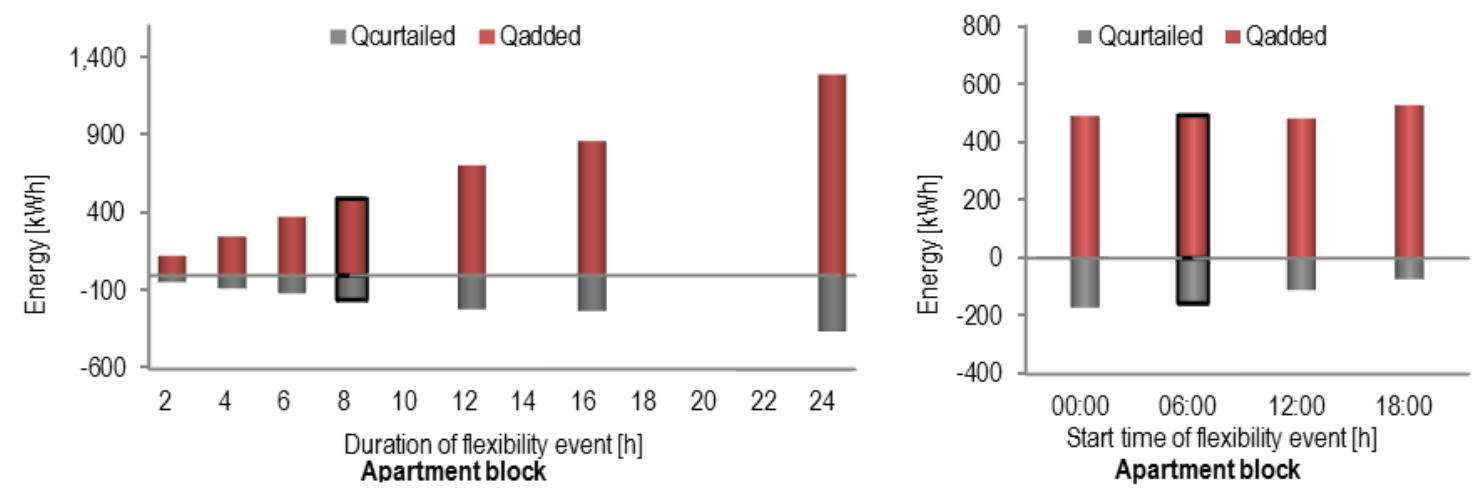

Figure 11: Energy added/curtailed during upward/downward flexibility events with different durations (left) and different starting time (right) for the apartment block

Regarding the duration of the events, it can be seen that the increase of the amount of energy added and curtailed during the events was almost linear to the duration of the events. This is explained as, when the air temperature had reached $24^{\circ} \mathrm{C}$, the surface temperature of the walls was still lower than the air temperature, so heat continued being absorbed by the wall elements until the end of the event, as depicted in Figure 12 for the base case flexibility event in the single-family house.

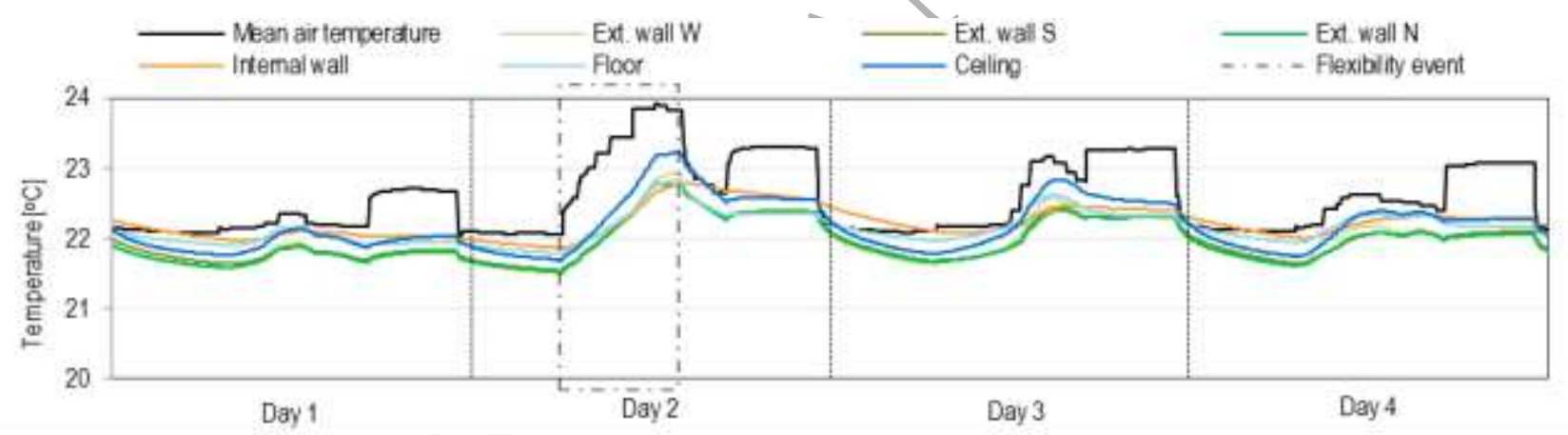

Figure 12: Indoor air and wall surface temperatures during the 8-hour event for the single-family house (day zone)

For the single-family house the potential for upward flexibility varied between $20 \mathrm{Wh} / \mathrm{m}^{2}$ for a 2-hour event and 180 $\mathrm{Wh} / \mathrm{m}^{2}$ for a 24 -hour event, while the potential for downward flexibility varied between $13 \mathrm{Wh} / \mathrm{m}^{2}$ for a 2 -hour event and $98 \mathrm{Wh} / \mathrm{m}^{2}$ for a 24 -hour event. Similarly for the apartment block, the potential for upward flexibility varied between $20 \mathrm{Wh} / \mathrm{m}^{2}$ for a 2 -hour event and $206 \mathrm{Wh} / \mathrm{m}^{2}$ for a 24-hour event, while for the downward event the flexibility potential varied between $7 \mathrm{Wh} / \mathrm{m}^{2}$ for a 2-hour event and $57 \mathrm{Wh} / \mathrm{m}^{2}$ for a 24 -hour event.

Regarding the start time of the events, the influence is more evident for the available energy to be curtailed rather than added. The potential for added energy is almost the same in all cases, apart from the event starting at 00:00 in the single-family house, which was lower by $18 \%$. The reason for this is that during the night the heating demand for space heating of the building (without modulations) is higher than during the day because of lower heat gains. Thereby, the 
energy that can be added during the upward flexibility event is less, due to the limited capacity of the space heating system. For both buildings, the potential for curtailment is highest at night-time (00:00 and 06:00), while it decreases almost by half during day time (12:00 and 18:00). During the day, the internal and/or solar gains were substantial, thus the heating demand was lower, hence the potential for curtailment was lower.

Similar modulations were performed by [14] and [16]. The former simulated available capacities for the Belgian building stock under static and dynamic boundary conditions. When comparing for the upward modulation of $2^{\circ} \mathrm{C}$ for 2 hours, using dynamic boundary conditions for a renovated single-family house, it was found that the available capacity was $43 \mathrm{Wh} / \mathrm{m}^{2}$. For the same modulation to a passive single-family house studied by [16], the capacity found was around $25 \mathrm{Wh} / \mathrm{m}^{2}$. In this study, for the upward modulation of 2 hours shown in Figure 10, the capacity found was $3 \mathrm{kWh}$ or 20 $\mathrm{Wh} / \mathrm{m}^{2}$. The deviations can be attributed to the differences in boundary conditions and thermal properties of the buildings.

\subsection{Influence of boundary conditions}

Boundary conditions are crucial parameters in this study. The ambient weather conditions, although uncontrolable, should be considered before implementing a flexibility event. Figure 13 presents the energy flexibility under different weather conditions during the heating season as presented in Section 2.3, namely cold, moderate and warm ambient air temperature with cloudy or clear sky. The base case flexibility events are outlined with black colour. The start time and duration are those of the base case flexibility events, namely started at 06:00 and lasted for 8 hours.
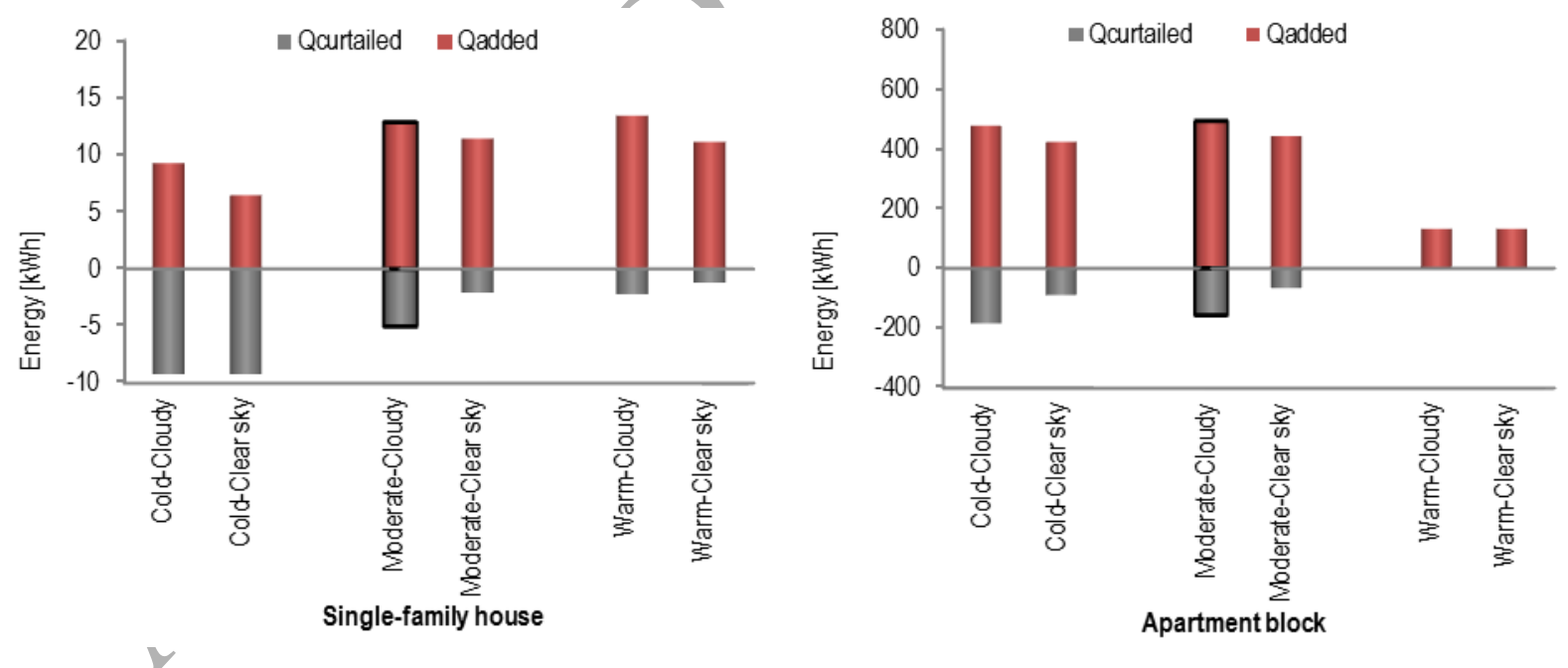

Figure 13: Energy added/curtailed during upward/downward flexibility events under different weather conditions for the single-family house (left) and the apartment block (right)

In all cases with clear sky, thus more solar gains, the flexibility was decreased. For the flexibility upwards, the decrease was on average $15 \mathrm{Wh} / \mathrm{m}^{2}$ for the single-family house and $6 \mathrm{Wh} / \mathrm{m}^{2}$ for the apartment block. This is attributed to the fact that solar gains contributed significantly to the increase of the indoor temperature, so the contribution of the 
heating system was decreased. Therefore, the additional energy was lower compared to the cases with cloudy sky, hence the potential for additional energy was limited by the upper limit of thermal comfort. For the flexibility downwards, the decrease was on average $9 \mathrm{Wh} / \mathrm{m}^{2}$ for the single-family house and $10 \mathrm{Wh} / \mathrm{m}^{2}$ for the apartment block. This is attributed to the higher solar gains that lead to lower energy use of the reference case, thus lower amount of energy to be curtailed compared to the case with cloudy sky.

The ambient air temperature is also a determinant parameter for the energy flexibility. For warmer days of the heating season the flexibility was low as heating demand was low. For the single-family house the decrease was only marginal $\left(1 \mathrm{Wh} / \mathrm{m}^{2}\right.$ ) for the upward events, while it was $12 \mathrm{Wh} / \mathrm{m}^{2}$ for the downward events. For the apartment block, in warm days, both the upward and downward flexibility decreased drastically. For colder days, the upward flexibility was decreased by $3 \mathrm{Wh} / \mathrm{m}^{2}$ for the apartment block and $28 \mathrm{Wh} / \mathrm{m}^{2}$ for the single-family house. Since the reference energy need in this case was already high in order to meet the heating set-point, the potential for additional heating demand was low, being limited by the capacity of the heating system. On the other hand, since the reference energy need was higher, there was higher potential for curtailment, thus the flexibility potential downward was increased, only by $4 \mathrm{Wh} / \mathrm{m}^{2}$ for the apartment block, while by $38 \mathrm{Wh} / \mathrm{m}^{2}$ for the single-family house.

Along with the ambient weather, internal heat gains are also important boundary conditions, as it became apparent from the analysis of the results. Both the intensity and the schedule of internal heat gains significantly affect the heating profile of the buildings and consequently the potential for flexibility. Similar observations were also underlined by the passive house studied in [16]. In the present study, the occupant behaviour was modelled deterministically. Future research should include models with stochastic occupancy and occupant behaviour [41-44] in order to improve the realism of energy flexibility quantification. Furthermore, research is required to what extent occupants would be willing to accept the influences on thermal comfort if their buildings should be operated flexibly. This may be more critical when using thermal mass as means to facilitate flexibility, than if flexibility is provided by components of the DHW systems of buildings. In order to achieve a flexible energy system, informed and motivated occupants are essential [45].

\subsection{Influence of building design parameters}

To study the impacts of design parameters on energy flexibility, building models were created for every variation shown in Table 4. For every building model, its reference operation, i.e. operation without flexibility modulations, was simulated. This reference operation was then compared to the upward and downward flexibility events, which every time started at 06:00 and lasted for 8 hours. Figure 14 presents the energy use of these three operation modes. Every bar represents one variation of the building model. The grey section of the bar shows the energy that was curtailed during the 
downward flexibility event, the red section of the bar shows the energy that was added during the upward flexibility event, while the white patterned section of the bar shows the energy use under the reference operation for the respective duration. The results of the baseline building are outlined with black colour for each parameter.
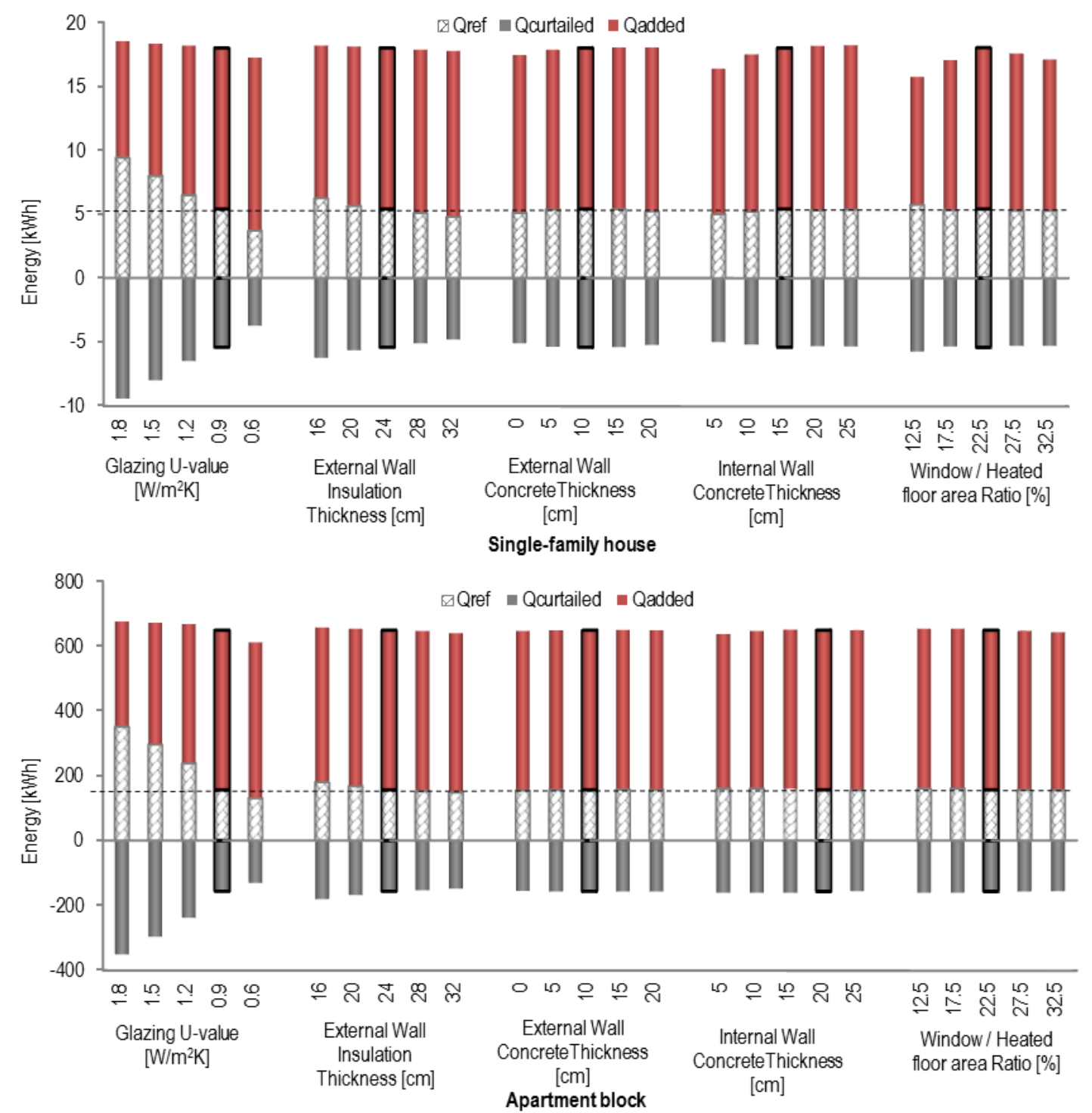

Figure 14: Energy during reference operation and energy added/curtailed during upward/downward flexibility events with different geometry characteristics of the single-family house (top) and the apartment block (bottom)

As explained in Section 2.4, when varying the window U-value or the external wall insulation thickness, the capacity of thermal mass remained unaltered to evaluate the effect of the buildings' heat losses on the flexibility potential. Similar results were obtained for both building types. The upward flexibility decreased as heat losses increased since the heating system has a limited capacity. For the variation with the highest losses, the potential for upward flexibility decreased by $28 \%$ for the single-family house and by $34 \%$ for the apartment block. On the other hand, the downward flexibility increased as heat losses increased; for the variation with the highest losses, the increase was $75 \%$ for the single-family 
house and $125 \%$ for the apartment block. The reason for this is that for the buildings with higher losses, the energy use during their reference operation was higher, so there was more energy to be curtailed during the downward flexibility event. The magnitude of the effect was greater for the glazing U-value, because among the parameters examined, the heat loss coefficient of the buildings was affected mostly by the window U-value.

In order to evaluate the effect of the thermal capacity, the external and internal wall concrete thicknesses were examined. There was no significant change (less than $5 \%$ between variations) in energy flexibility when the thickness of the external wall was changed, since the thermal capacity of walls is limited by the penetration depth inside the concrete. Considering the concrete as thermal mass element rather than structural element, it appears that there is no benefit gained by adding concrete thickness greater than $10 \mathrm{~cm}$ for the external walls and $15 \mathrm{~cm}$ for the internal walls, which is in line with the outcome of [46]. Nevertheless, the contribution of the thermal capacity of the internal walls was shown to be higher than that of the external walls. This finding was indeed expected, since the internal walls are exposed to the indoor air on both sides, while the external walls are only exposed on one side. Also, the material of the internal loadbearing walls is concrete, whereas for the external walls it is aerated concrete, which has smaller thermal capacity. For the single-family house, the variation with $5 \mathrm{~cm}$ internal walls resulted in $10 \%$ lower potential for upward flexibility and $8 \%$ lower potential for downward flexibility. The relative effect of thermal capacity of walls in the apartment block appeared smaller compared to the effect in the single-family house, since there is a large amount of concrete in the ceiling decks of the apartment block. For the baseline single-family house, the shares in the total effective thermal mass of external walls, internal walls, floor and roof are $10 \%, 28 \%, 55 \%$ and $7 \%$ respectively. For the baseline apartment block the shares of external walls, internal walls, floor, roof and floor/ceiling decks are $2 \%, 20 \%, 4 \%, 4 \%$ and $70 \%$ respectively.

The obtained results are for the investigated type of buildings and should be very carefully assessed in order to be extended to other building types. For all variations examined, the buildings remained in the category of heavy buildings, apart from the variation with $5 \mathrm{~cm}$ internal walls for single-family house, which is in the category of semi-light buildings according to the Danish Building Research Institute (SBi) Guidelines 'Energy Demand for Buildings' [28].

The effect of window/heated floor area ratio was complicated as three main elements changed simultaneously: thermal capacity, heat losses and solar gains. For the single-family house, when the ratio either increased or decreased from the baseline building, the upward flexibility potential decreased. The change in downward flexibility was not 
significant. For the apartment block the behaviour was different, as the effect of the different elements seemed to counterbalance each other and the potential remained unaltered for all variations.

The time constant of all the building models was calculated and the added or curtailed energy during the base case upward (red) or downward (grey) flexibility events are plotted in Figure 15.
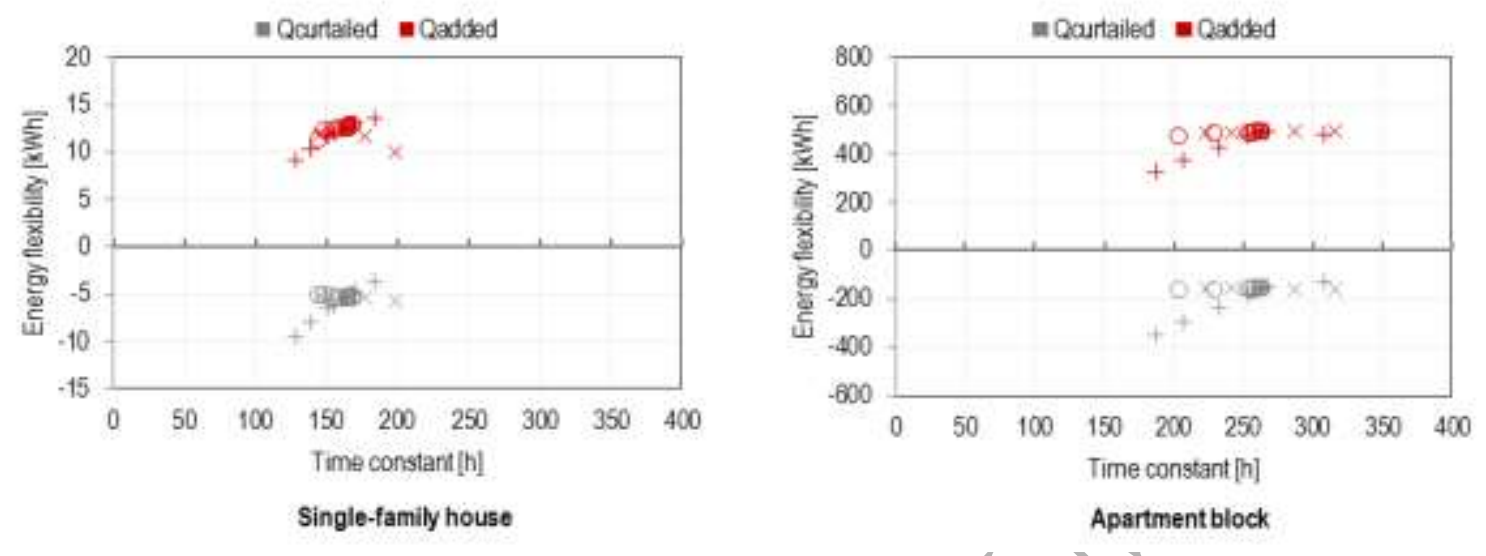

Figure 15: Correlation between flexibility potential and time constant for all variations examined for the single-family house (left) and the apartment block (right). Buildings' variations concerning heat loss effect are marked as + , those concerning thermal capacity effect are marked as $\circ$, those concerning the combination of the previous two and the solar gains are marked as $\times$.

On average, the time constant of the single-family house was shorter, compared to the respective of the apartment block. This is attributed mainly to the ratio of the envelope area per volume of the apartment block $\left(0.265 \mathrm{~m}^{2} / \mathrm{m}^{3}\right) \mathrm{being}$ considerably lower than the one for the single-family house $\left(0.998 \mathrm{~m}^{2} / \mathrm{m}^{3}\right)$. In the apartment block, a broader range of results for the time constant was observed, although the changes in the building design parameters were the same. Furthermore, in the apartment block there were two clear trends observed, one formed from the variations concerning heat losses (marked as + in the figure) and the other from those concerning the thermal mass effect (marked as $\circ$ in the figure), with the distinction between them being evident. In the single-family house, the behaviour was similar for the downward flexibility potential. However, for the upward flexibility potential a correlation can be observed, which was in this case disturbed only by the solar gains (marked as $x$ in the figure). Although the time constant of the buildings appears not to be enough as an indicator with regards to energy flexibility from building thermal mass and heating systems, it can however indicate the range of the potential.

With the building design parameters examined, it was shown that the characteristic to be prioritized when aiming for energy flexibility is the minimization of heat losses. Once this is ensured, it would be beneficial to increase the thermal capacity of the building as well, especially that of the internal walls. The effect of the glazing area did not present a clear trend, hence no direct guideline can be suggested from the obtained results. However, there might be other design 
parameters important for investigation. For example, different zoning of the buildings, i.e. different sizes of apartments, orientation, uses, interior design, shading, etc., would also impact the thermal behaviour of the buildings. Furthermore, in this study only sensible heat storage has been considered. The integration of phase changing materials in the structural thermal mass of the building could also be considered, as reviewed by [10].

\section{Conclusions}

We investigated flexibility potential for new buildings, considering the heating energy that can be added to or curtailed from the buildings for a certain period of time without compromising thermal comfort for the occupants. Two building types were modelled in the building performance simulation software IDA ICE: a single-family hoúse and an apartment block. Both are well-insulated heavy-weight buildings following the Danish Building Regulation 2015. A scenario for reference operation of the buildings with constant heating temperature set-point at $22^{\circ} \mathrm{C}$ was initially simulated. Two deviations from this reference were considered with increased set-point to $24^{\circ} \mathrm{C}$ or decreased set-point to $20^{\circ} \mathrm{C}$ for a period of time. The first case (upward flexibility event) represented a scenario with abundance of renewable energy production in the energy system, when the heat supply in a building can be increased, in order for thermal energy to be stored in the thermal mass. The second (downward flexibility event) represented a scenario with limited/no availability of renewable energy in the energy system, when the heat supply in buildings needs to be curtailed or completely interrupted.

During flexibility events under moderate weather conditions of the Danish heating season, starting at 06:00 and lasting for 8 hours, the heating energy added to the single-family house was $87 \mathrm{Wh} / \mathrm{m}^{2}$ and the energy curtailed was $36 \mathrm{Wh} / \mathrm{m}^{2}$; while the heating energy added to the apartment block was $76 \mathrm{Wh} / \mathrm{m}^{2}$ and the energy curtailed was $25 \mathrm{Wh} / \mathrm{m}^{2}$. In all cases examined, clear asymmetries between the amount of added and curtailed energy were noticed. Although for individual buildings, the amount of energy to be curtailed is limited, if aggregated to a neighbourhood or district level, the amount of energy available for curtailment becomes significant. At the same time, in cases of abundant production of renewable energy in the system, the buildings can act as storage media absorbing considerable quantities of thermal energy in the

structural thermal mass. Furthermore, the findings show that low-energy buildings are highly robust and can remain autonomous for several hours maintaining thermal comfort.

It was shown that the amount of energy added/curtailed during the event was proportional to the duration of the event, which indicates that the buildings have large heat capacity. The different starting time of the flexibility events mainly affected the potential for curtailment, with the highest available energy to be curtailed being during the night. The analysis presented high dependence of flexibility potential on boundary conditions, namely ambient temperature, solar 
radiation and internal gains. The potential for curtailment increased during cold days, while the potential for storing additional energy was highest during days with moderate ambient temperature for the heating season. Increased solar gains led to decreased flexibility potential. From the different building design parameters examined, it shown that heat losses to the ambient govern the potential for flexibility, while the concrete thickness of the walls was not a determinant factor by itself. The contribution of the thermal capacity of the internal walls was shown to be higher than that of the external walls.

This work provided a deep insight into thermal behaviour of low-energy buildings and their physical potential for energy flexibility. The results can be extended with aggregation studies creating a category of such buildings that can be added to the portfolio of solutions for storage in the energy system, thus facilitating higher penetration of renewable energy. Feasibility studies need to be performed to assess the active participation of buildings in the energy market, as appropriate business models for flexibility services are yet to be developed. Finally, further studies will be needed on occupants' thermal comfort, acceptability and behavioural response.

\section{Acknowledgements}

This research is part of the Danish research project "EnergyLab Nordhavn - New Urban Energy Infrastructures" supported by the Danish Energy Technology Development and Demonstration Programme (EUDP). Project number: 64014-0555. This work is also part of research activities of IEA-EBC Annex 67 (International Energy Agency - Energy in Buildings and Communities programme) Energy Flexible Buildings.

\section{Appendix}

The total heat capacity is given by Equation (A.1) [47], as the sum of the capacity of the individual building components: Total heat capacity $=\sum \rho \cdot C_{p} \cdot A \cdot d, \quad($ A.1), where:

$\rho$, the density of the material $\left[\mathrm{kg} / \mathrm{m}^{3}\right]$,

$C_{p}$, the specific heat capacity of the material $[\mathrm{J} /(\mathrm{kg} \cdot \mathrm{K})]$,

$A$, the surface area of the material $\left[\mathrm{m}^{2}\right]$,

$d$, the depth $[\mathrm{m}]$ of the layer of the material considered. Only materials on the inner side of the insulation layer were considered.

If the depth of the material was higher than the penetration depth of the material, then the penetration depth was

used for $d$. The penetration depth is calculated according to Equation (A.2): $d=\sqrt{\frac{a \cdot t}{\pi}} \quad$ (A.2) [47], where: 
$t$, the duration of the period [s], in this work considered as one day,

$\alpha$, the thermal diffusivity, $\left[\mathrm{m}^{2} / \mathrm{s}\right]$.

The methodology corresponds to the simplified calculation of the heat capacity of the standard EN ISO 13786 [48], but in this work the thermal diffusivity is calculated for each material, instead of using the conventional value mentioned in the standard.

\section{References}

[1] European Commission, European Council 23-24/10/2014 - Conclusions on 2030 Climate and Energy Policy Framework, Brussels, Belgium, 2014.

[2] Danish Energy Agency, Danish climate policies, (2017). https://ens.dk/en/our-responsibilities/energy-climatepolitics/danish-climate-policies (accessed November 19, 2017).

[3] P. Denholm, M. Hand, Grid flexibility and storage required to achieve very high penetration of variable renewable electricity, Energy Policy. 39 (2011) 1817-1830. doi:10.1016/j.enpol.2011.01.019.

[4] S.Ø. Jensen, A. Marszal-Pomianowska, R. Lollini, W. Pasut, A. Knotzer, P. Engelmann, A. Stafford, G. Reynders, IEA EBC Annex 67 Energy Flexible Búildings, Energy Build. 155 (2017) 25-34. doi:10.1016/j.enbuild.2017.08.044.

[5] A. Marszal-Pomianowska, P. Heiselberg, O. Kalyanova Larsen, Household electricity demand profiles - A highresolution load model to facilitate modelling of energy flexible buildings, Energy. 103 (2016) 487-501. doi:10.1016/j.energy.2016.02.159

[6] R. D'hulst, W. Labeeuw, B. Beusen, S. Claessens, G. Deconinck, K. Vanthournout, Demand response flexibility and flexibility potential of residential smart appliances: Experiences from large pilot test in Belgium, Appl. Energy. 155 (2015) 79-90. doi:10.1016/j.apenergy.2015.05.101.

[7] J. Heier, C. Bales, V. Martin, Combining thermal energy storage with buildings - a review, Renew. Sustain. Energy Rev. 42 (2015) 1305-1325. doi:10.1016/j.rser.2014.11.031.

[8] H. Wolisz, H. Harb, P. Matthes, Dynamic simulation of thermal capacity and charging/discharging performance for sensible heat storage in building wall mass, in: 13th Conf. Int. Build. Perform. Simul. Assoc., Chambery, France, 2013: pp. 2716-2723.

[9] B. Favre, B. Peuportier, Application of dynamic programming to study load shifting in buildings, Energy Build. 82 (2014) 57-64. doi:10.1016/j.enbuild.2014.07.018. 
[10] H. Johra, P. Heiselberg, Influence of internal thermal mass on the indoor thermal dynamics and integration of phase change materials in furniture for building energy storage: A review, Renew. Sustain. Energy Rev. 69 (2017) 19-32. doi:10.1016/j.rser.2016.11.145.

[11] C. Finck, R. Li, R. Kramer, W. Zeiler, Quantifying demand flexibility of power-to-heat and thermal energy storage in the control of building heating systems, Appl. Energy. 209 (2018) 409-425. doi:10.1016/j.apenergy.2017.11.036.

[12] A. Arteconi, N.J. Hewitt, F. Polonara, Domestic demand-side management (DSM): Role of heat pumps and thermal energy storage (TES) systems, Appl. Therm. Eng. 51 (2013) 155-165. doi:10.1016/j.applthermaleng.2012.09.023.

[13] S. Stinner, K. Huchtemann, D. Müller, Quantifying the operational flexibility of building energy systems with thermal energy storages, Appl. Energy. 181 (2016) 140-154. doi:10.1016/j.apenergy.2016.08.055.

[14] G. Reynders, J. Diriken, D. Saelens, Generic characterization method for energy flexibility: Applied to structural thermal storage in residential buildings, Appl. Energy. 198 (2017) 192-202. doi:10.1016/j.apenergy.2017.04.061.

[15] G. Masy, E. Georges, C. Verhelst, V. Lemort, Smart grid energy flexible buildings through the use of heat pumps and building thermal mass as energy storage in the Belgian context, Sci. Technol. Built Environ. 4731 (2015) 800-811. doi:10.1080/23744731.2015.1035590.

[16] J. Le Dréau, P. Heiselberg, Energy flexibility of residential buildings using short term heat storage in the thermal mass, Energy. 111 (2016) 991-1002. doi:10.1016/j.energy.2016.05.076.

[17] K.O. Aduda, T. Labeodan, W. Zeiler, G. Boxem, Demand side flexibility coordination in office buildings: A framework and case study application, Sustain. Cities Soc. 29 (2017) 139-158. doi:10.1016/j.scs.2016.12.008.

[18] TABULA WebTool, (2017). http://webtool.building-typology.eu (accessed October 11, 2017).

[19] H. Wolisz, P. Block, R. Streblow, D. Müller, Dynamic activation of structural thermal mass in a multizonal building with due regard to thermal comfort, 14th Int. Conf. IBPSA - Build. Simul. 2015, BS 2015, Conf. Proc. (2015) 1291-1297.

[20] G. Reynders, T. Nuytten, D. Saelens, Potential of structural thermal mass for demand-side management in dwellings, Build. Environ. 64 (2013) 187-199. doi:10.1016/j.buildenv.2013.03.010.

[21] J. Kensby, A. Trüschel, J.-O. Dalenbäck, Potential of residential buildings as thermal energy storage in district heating systems - Results from a pilot test, Appl. Energy. 137 (2015) 773-781. doi:10.1016/j.apenergy.2014.07.026. 
[22] D. Six, J. Desmedt, J.V.A.N. Bael, D. Vanhoudt, Exploring the Flexibility Potential of Residential Heat Pumps, 21st Int. Conf. Electr. Distrib. (2011) 6-9.

[23] T. Péan, J. Ortiz, J. Salom, Impact of Demand-Side Management on Thermal Comfort and Energy Costs in a Residential nZEB, Buildings. 7 (2017) 37. doi:10.3390/buildings7020037.

[24] The Danish Transport and Construction Agency, Danish Building Regulations 2015, (2015).

[25] EN/DS 15251, Indoor environmental input parameters for design and assessment of energy performance of buildings addressing indoor air quality, thermal environment, lighting and acoustics, Dansk Stand. (2007) 54.

[26] F. Oldewurtel, D. Sturzenegger, G. Andersson, M. Morari, R.S. Smith, Towards a standardized building assessment for demand response, Proc. IEEE Conf. Decis. Control. (2013) 7083-7088. doi:10.1109/CDC.2013.6761012.

[27] D. Fischer, T. Wolf, J. Wapler, R. Hollinger, H. Madani, Model-based flexibility assessment of a residential heat pump pool, Energy. 118 (2017) 853-864. doi:10.1016/j.energy.2016.10.111.

[28] S. Aggerholm, K. Grau, Bygningers energibehov - Beregningsvejledning - SBi-anvisning 213, Aalborg, 2014.

[29] DS 418, Beregning af bygningers varmetab - Calculation of heat loss from buildings, Dansk Stand. (2011).

[30] DS/EN ISO 13370, Thermal performance of buildings - Heat transfer via the ground - Calculation methods, Dansk Stand. 2. udgave (2008).

[31] EQUA Simulation AB, IDA Indoor Climate and Energy - A new generation building performance simulation software, IDA Indoor Clim. Energy. (2017). https://www.equa.se/en/ida-ice.

[32] EQUA Simulation AB, Validation of IDA Indoor Climate and Energy 4 . 0 with respect to CEN Standards EN 15255-2007 and EN 15265-2007, Solna, Sweden, 2010.

[33] EQUA Simulation AB, Validation of IDA Indoor Climate and Energy 4.0 build 4 with respect to ANSI/ASHRAE Standard 140-2004, Solna, Sweden, 2010.

[34] S. Kropf, G. Zweifel, Validation of the Building Simulation Program IDA-ICE According to CEN 13791 , Thermal Performance of Buildings - Calculation of Internal Temperatures of a Room in Summer Without Mechanical Cooling - General Criteria and Validation Procedures “, 2001.

[35] P. Loutzenhiser, H. Manz, G. Maxwell, International Energy Agency’s SHC Task 34 - ECBCS Annex 43 Project

C: Empirical Validations of Shading / Daylighting / Load I nteractions in Building Interactions Energy Simulation Tools, 2007.

[36] S. Moosberger, Test of IDA Indoor Climate and Energy version 4.0 according to CIBSE TM33, Luzern, 2007. 
[37] P.G. Wang, M. Scharling, K.P. Nielsen, K.B. Wittchen, C. Kern-Hansen, Technical Report 13-19 2001 - 2010 Danish Design Reference Year - Reference Climate Dataset for Technical Dimensioning in Building, Construction and other Sectors, Copenhagen, 2013.

DS/EN ISO 13790, Energy performance of buildings - Calculation of energy use for space heating and cooling, Dansk Stand. (2008) 178.

[39] L.-S. Wang, P. Ma, E. Hu, D. Giza-Sisson, G. Mueller, N. Guo, A study of building envelope and thermal mass requirements for achieving thermal autonomy in an office building, Energy Build. 78 (2014) 79-88. doi:10.1016/j.enbuild.2014.04.015.

[40] E. Georges, B. Cornélusse, D. Ernst, V. Lemort, S. Mathieu, Residential heat pump as flexible load for direct control service with parametrized duration and rebound effect, Appl. Energy. 187 (2017) 140-153. doi:10.1016/j.apenergy.2016.11.012.

[41] J. Widén, M. Lundh, I. Vassileva, E. Dahlquist, K. Ellegård, E. Wäckelgård, Constructing load profiles for household electricity and hot water from time-use data-Modelling approach and validation, Energy Build. 41 (2009) 753-768. doi:10.1016/j.enbuild.2009.02.013.

[42] J. Widén, A. Molin, K. Ellegård, Models of domestic occupancy, activities and energy use based on time-use data: Deterministic and stochastic approaches with application to various building-related simulations, J. Build. Perform. Simul. 5 (2012) 27-44. doi:10.1080/19401493.2010.532569.

[43] A. Wang, R. Li, S. You, Development of a data driven approach to explore the energy flexibility potential of building clusters, Appl. Energy. (2018). (under review).

[44] R. Li, F. Wei, Y. Zhao, W. Zeiler, Implementing Occupant Behaviour in the Simulation of Building Energy Performance and Energy Flexibility: Development of Co-Simulation Framework and Case Study, Proc. Build. Simul. 2017. (2017)1339-1346.

[45] R. Li, G. Dane, C. Finck, W. Zeiler, Are building users prepared for energy flexible buildings?-A large-scale survey in the Netherlands, Appl. Energy. 203 (2017) 623-634. doi:10.1016/j.apenergy.2017.06.067.

[46] P. Ma, L.-S. Wang, Effective heat capacity of interior planar thermal mass (iPTM) subject to periodic heating and cooling, Energy Build. 47 (2012) 44-52. doi:10.1016/j.enbuild.2011.11.020.

[47] H.E. Hansen, P. Kjerulf-Jensen, B.O. Stampe, Varme- og klimateknik : Grundbog, DANVAK, 1988.

[48] DN/EN ISO 13786, Thermal performance of building components - Dynamic thermal characteristics Calculation methods, Dansk Stand. (2008). 